\title{
20. POLLEN STRATIGRAPHY AND PALEOECOLOGIC INTERPRETATION OF THE 160-K.Y. RECORD FROM SANTA BARBARA BASIN, HOLE 893A ${ }^{1}$
}

\author{
Linda E. Heusser²
}

\begin{abstract}
Pollen data ( 159 samples taken at $\sim \leq 1000 \mathrm{yr}$ intervals) provide the first continuous, chronologically controlled record of southern California terrestrial environments over the past 160 k.y., a record that is directly correlated with changes in the marine environment inferred from organic and inorganic components of the same sediment samples. In the well-laminated sediments deposited during the last interglacial interval, pollen assemblages are characterized by Quercus and other taxa similar to those of present arid coastal biomes (e.g., oak woodland, chaparral, coastal sage scrub, and salt marsh). Pollen assemblages in the massive glacial sediments, dominated by conifers (referable to the Taxodiaceae, Cupressaceae, Taxaceae, and Pinaceae families) imply altitudinal and latitudinal expansion of montane conifer woodland and forest associations (e.g.. juniper woodlands and yellow pine forests of the Transverse Ranges). Variable representation of oak woodland and coniferous forests characterizes interstadials and stadials.

During the last glacial maximum on the south coast of California, mean annual temperature and effective precipitation estimates inferred from pollen data in Santa Barbara Basin are $\sim 5^{\circ} \mathrm{C}$ and $\sim 1000 \mathrm{~mm}$. respectively. Interglacial temperatures and evapotranspiration were comparable to or possibly higher than at present. High-frequency variability in the pollen/vegetation assemblages from Ocean Drilling Program Hole 893A implies frequent and rapid change between these two climatic endmembers throughout the last 160 k.y. For example, following an abrupt warming at $\sim 14$ k.y., a brief mesic, cooling event precedes the development of Holocene interglacial conditions.

Systematic variations in the pollen assemblages deposited in Santa Barbara Basin are similar in amplitude and duration to changes reconstructed from oxygen isotopes in the same sediment samples. The apparent synchroneity of the terrestrial (pollen/ vegetation of south coastal California) and marine (oxygen isotope) proxy climate signals from Hole 893A concurs with previous results from the North and South Pacific which showed similar rapid responses of terrestrial ecosystems to global climate change during the last glacial cycle.
\end{abstract}

\section{INTRODUCTION}

Ocean Drilling Program (ODP) Hole 893A $\left(34^{\circ} 17.25^{\prime} \mathrm{N}\right.$, $120^{\circ} 02.19^{\prime} \mathrm{W}, 576.5$ meters below seafloor [mbsf]) was drilled $\sim 20$ $\mathrm{km}$ from the southern California coastline in Santa Barbara Basin (Fig. 1), a small near-shore, silled basin containing rapidly deposited $(\sim 100 \mathrm{~cm} / \mathrm{k} . \mathrm{y}$.$) , upper Quaternary interbedded laminated, nonlami-$ nated, and bioturbated sediment (Shore-based Scientific Party, 1994). Retrieval of a continuous 195-m sedimentary sequence covering the last 161 k.y. provides an opportunity to use pollen analysis to document the nature of coastal southern California vegetation throughout the last glacial cycle, and to determine the response of these terrestrial ecosystems to local and global paleoceanographic and paleoclimatic changes over the past $160 \mathrm{k} . \mathrm{y}$. Previous studies elsewhere in the North and South Pacific, which demonstrated a close relationship between coastal terrestrial environments and ocean/atmospheric forcing, suggest that changes in onshore environments reflected in the pollen assemblages deposited in Santa Barbara Basin would be synchronous with global climate changes (Heusser, L.E., 1978; Heusser and Shackleton, 1979; Heusser and van de Geer, 1994).

Pacific ocean-atmosphere interaction is the major determinant of the character and distribution of the dominant hydrographic features

'Kennett, J.P., Baldauf, J.G., and Lyle. M. (Eds.), 1995. Proc. ODP. Sci. Results. 146 (Pt. 2): College Station, TX (Ocean Drilling Program).

Lamont-Doherty Earth Observatory of Columbia University, Palisades, NY 10964 and Heusser and Heusser Inc.. Tuxedo. NY 10987, U.S.A. of Santa Barbara Basin and of onshore climate. Seasonal variations in the California Current system reflect the direction and intensity of the westerlies. Strong northerly winds between April and August enhance flow of the cold California Current toward the equator. Weakening of the northerlies in fall and winter results in intensified flow toward the poles of the warm surface waters of the Davidson Current and inhibits significant upwelling along the margin. Decadal, El Niño-Southern Ocean (ENSO)-related variations in sea-surface temperature are associated with onshore changes in precipitationwarm sea-surface temperatures with high precipitation during $\mathrm{El}$ Niño events and cool sea-surface temperatures with dry La Niña conditions (Namias, 1971).

The mild, arid Mediterranean (winter wet, summer dry) climate of coastal southern California is further moderated by fog formed by the passage of warm air over a semipermanent band of cold upwelling water during summer months and by warm offshore waters in winter (Pisias, 1978). Consequently, mean annual temperature is low $\left(\sim 14^{\circ} \mathrm{C}\right)$ and the annual range of mean monthly temperature onshore is small (January $11^{\circ} \mathrm{C}$-July $17^{\circ} \mathrm{C}$ ). Away from the moderating influence of the ocean, $\sim 19 \mathrm{~km}$ inland, temperatures are $\sim 4^{\circ}$ higher in summer and $1.4^{\circ}$ colder in winter (Barbour and Major, 1977). Above the coastal fog at $\sim 800 \mathrm{~m}$ elevation, summer temperatures rise to $25^{\circ} \mathrm{C}$, and on the peaks of the western Transverse Range maximum summer temperatures may exceed those of the lowland (Elford, 1974). Most of the limited and variable precipitation, which annually ranges from $\leq 30 \mathrm{~cm}$ on the lowland to $\sim 50-100 \mathrm{~cm}$ on the mountains north of Santa Barbara Basin, is produced in winter by intense, episodic North Pacific frontal storms (Elford, 1974; Peterson, 1980). Subtropical monsoons and local convective storms provide occasional rain in summer. 


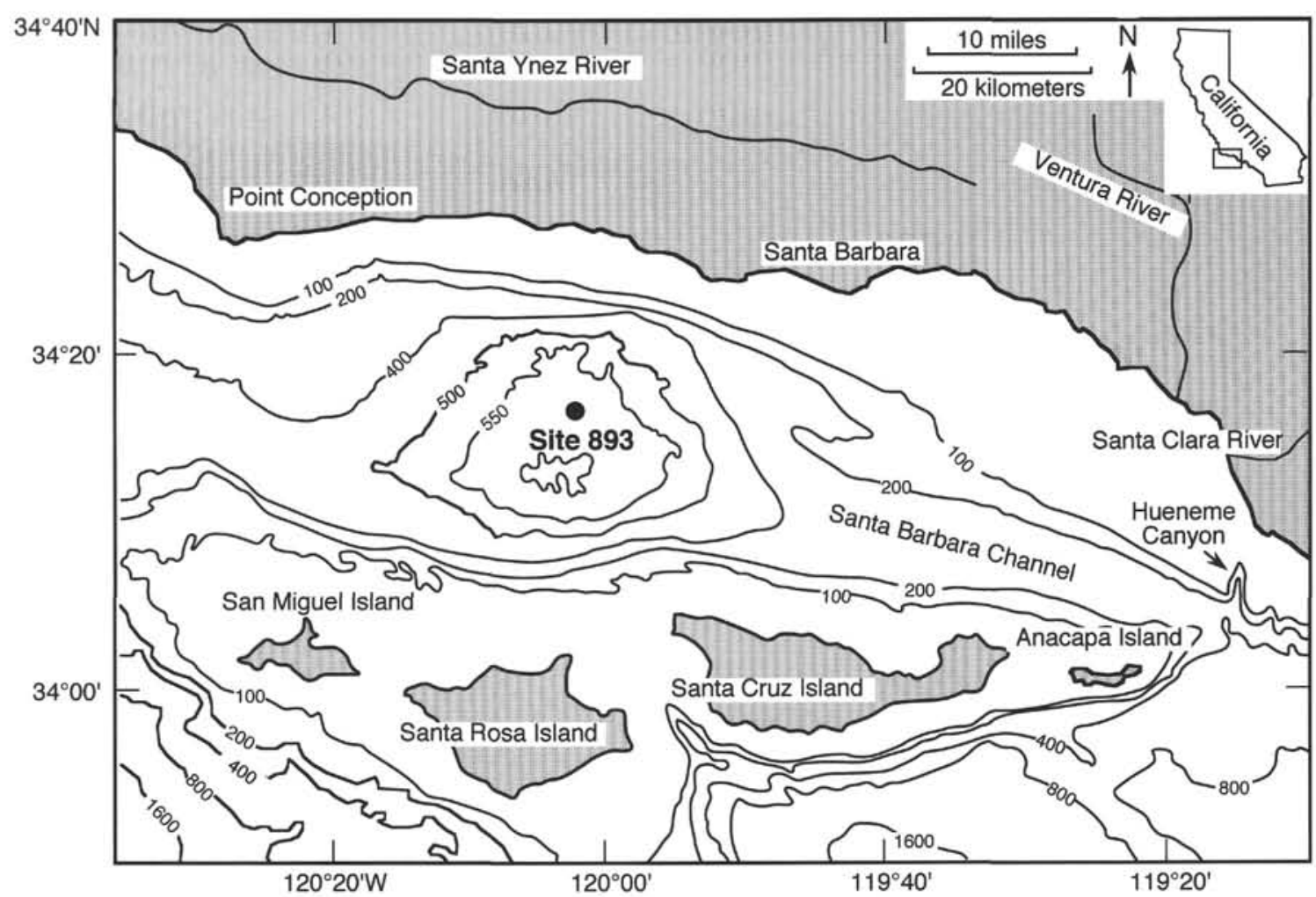

Figure 1. Map of Santa Barbara Channel showing the location of ODP Site 893 in Santa Barbara Basin.

Southern California vegetation around the Santa Barbara Basin is a dynamic landscape mosaic of coastal plant associations that vary with altitude, substrate, topography, and fire history (Barbour and Major, 1977; Barbour and Billings, 1988) (Table 1). The natural vegetation of the narrow coastal plain consists of coastal sage scrub or soft chaparral (including summer deciduous, semi-woody plants such as Artemisia, Salvia, and Eriogonum) that interfingers with chaparral (sclerophylous shrubs such as Ceanothus, Adenostoma, Rhus and other members of the Anacardiaceae, Rhamnaceae, and Rosaceae), scrub oak (Quercus dumosa) and oak (Q. agrifolia) woodland savanna (Griffin, 1977; Hanes, 1977; Mooney, 1977; Keeley and Keeley, 1988). Salt marshes are not numerous or extensive around Santa Barbara Basin. Foothill woodlands are dominated by $Q$. agrifolia (live oak).

On the lower slopes of the Transverse Ranges at $\sim 600 \mathrm{~m}$, mixed hardwood (Q. agrifolia) forest merges with open pine (Pinus coulteri and $P$. sabiniana) woodland in which small stands of incense-cedar (Libocedrus decurrens) may occur. These mixed evergreen forests and open, park-like mid-montane conifer forests with yellow pine $(P$. ponderosa and $P$. jeffreyi), incense cedar, and oaks ( $Q$. kelloggii $)$ are

Table 1. Distribution of major vegetation types of south coastal California in relation to elevation.

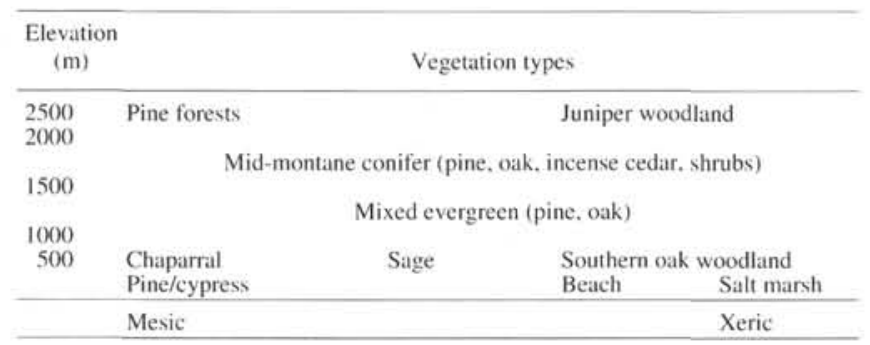

found between 800 and $1400 \mathrm{~m}$. The latter extends to $2600 \mathrm{~m}$. In Southern California, mean annual temperature (MAT) and annual precipitation in the mid-montane forests are $\sim 13^{\circ} \mathrm{C}$ and $850 \mathrm{~mm}$, respectively. Within the forest, MATs decrease to $\sim 11^{\circ} \mathrm{C}$ and precipitation increases to $>1000 \mathrm{~mm}$ (Barbour, 1988). Upper montane juniper (Juniperus occidentalis) woodland and subalpine coniferous ( $P$. contorta) forests occur between 2400 and $2800 \mathrm{~m}$ in the higher eastern Transverse Ranges. Although there is little difference in total annual precipitation between the mid and upper montane forests, more precipitation occurs as snow in the higher elevation forests due to the lower MAT $\left(\sim 5^{\circ} \mathrm{C}\right)$. The comparatively small area of the Santa Ynez Mountains above $1500 \mathrm{~m}$ and the desert slopes of the Transverse Ranges are occupied by piñon pine-juniper woodland $(P$. monophylla, J. californica) with understory shrubs such as Artemisia tridentata (Thorne, 1977; Callaway and Davis, 1993; Critchfield, 1971).

\section{METHODS}

One sample was taken from each section of the 21 cores recovered using the advanced piston corer from Hole $893 \mathrm{~A}$ for this initial pollen study. A few additional samples were later taken from Cores 146$893 \mathrm{~A}-\mathrm{IH}$ and $3 \mathrm{H}$, yielding a total of 159 samples from the $196.5 \mathrm{~m}$ of hemipelagic silty clays recovered from Santa Barbara Basin. Using sample depths adjusted for gas expansion (Rack and Merrill, this volume) and the chronostratigraphy generated by Merrill (this volume) from globally and regionally corrected AMS ${ }^{14} \mathrm{C}$ dates (Ingram and Kennett, this volume) and oxygen isotope stage (OIS) boundaries (Kennett, this volume), each $2-\mathrm{cm}^{3}$ pollen sample integrates an average of $\sim 20-30 \mathrm{yr}$, and sample resolution averages $\sim 1000 \mathrm{yr}$.

Dried samples ( $\sim 3-5 \mathrm{~g}$ dry-weight sediment [gdws]) were prepared with standard $\mathrm{HF}$ and acetolysis treatment, which was preceded and succeeded by screening through $7-\mu \mathrm{m}$ screens (Heusser and 
Stock, 1984). Identification of pollen was frequently hindered by the presence of organic agglomerates (possibly remains of algal mats, Soutar and Crill, 1977) and pyrite. Pollen types were identified to the lowest taxonomic level possible; for instance, Sarcobatus was differentiated from the Chenopodiaceae (which is indistinguishable from the Amaranthaceae), and Artemisia was tallied separately from other Compositae. In California, the inaperturate pollen grains of the Taxodiaceae, Cupressaceae, and Taxaceae - families that cannot be satisfactorily separated using light microscopy-are customarily referred to as TCT (an acronym formed from the first letter of the three families from which the pollen might be derived (Adam, 1988: Mensing, 1993). Possible sources of pollen from these three families in Santa Barbara Basin include Juniperus californica, J. occidentalis, Torreya californica, Cupressus macrocarpa, C. sargentii, and Libocedrus decurrens. J. californica is widely distributed, occurring in isolated groves or as an emergent in coastal sage scrub, chaparral and in canyon washes. J. occidentalis is found in montane-juniper woodlands in the Transverse Ranges (Barbour and Major, 1977). L. decurrens occurs in chaparral, mid-montane conifer forest, and lower montane woodlands; relict stands of $C$. sargentii are scattered along the coast. Regional Rosaceae, Rhamnaceae, and Anacardiaceae pollen grains, also difficult to separate using light microscopy, are also referred to by an acronym (RRA) derived from the initials of the three families).

In this preliminary survey, pollen percentages were calculated using the sum of terrestrial pollen, which was limited to $\geq 200$ pollen grains. Spores were not included in the pollen sum. (Final counts of $\sim 300$ pollen grains for each of the 159 samples analyzed for this study, as well as final counts from $\sim 400$ additional samples, were incorporated into the ODP database in 1995). To reduce the number of variables to a few independent, ecologically meaningful groups, pollen data were synthesized using Q-mode factor analysis. Mass-accumulation rates of pollen (PAR) were calculated using the number of pollen grains/gdws and bulk mass-accumulation rates (MAR) (Gardner and Dartnell, this volume).

\section{RESULTS}

Pollen is well preserved and abundant in Santa Barbara Basin sediment. Pollen concentration (pollen grains/gdws) is variable, ranging from $\sim 1,000 / \mathrm{gdws}$ to $180,000 / \mathrm{gdws}$, with an average concentration of $\sim 34,000 /$ gdws (Fig. 2). Pollen concentrations in the intermittently laminated sediments (lithologic Subunits IC, 37-131 mbsf, and IF, $160.5-196.5 \mathrm{mbsf})$, vary between the lowest values $(\sim 1,000 / \mathrm{gdws})$ in laminated sediment (lithologic Subunit 1A, 0-24.25 mbsf, and Subunit ID, 131-145.5 mbsf) to high values $(180,000 / \mathrm{gdws})$ found in the nonlaminated sediment (lithologic Subunit IB, 24.3-37 mbsf, and IE, 145.5-160.5 mbsf). When plotted vs. age (Fig. 3, left), pollen concentration does not appear to follow clearly a glacial-interglacial pattern. Although pollen concentrations are low during or close to interglacial intervals (e.g., OIS-1 and -5e) and high during glacial intervals (OIS-2 and -6 ), they are not high during OIS-4. Smoothed with a 3-point moving average, pollen concentrations do appear to vary systematically at $\sim 20-k . y$. intervals (Fig. 3, right), close to precessional periodicity of $23 \mathrm{k} . \mathrm{y} . / \mathrm{cycle}$. When corrected for annual sedimentation rates, however, accumulation rates of pollen (pollen grains $/ \mathrm{cm}^{2} / \mathrm{yr}=$ PAR) (Fig. 4) are noisy, and spectral analysis of PARs showed no power in the $10-$ and $20-k . y$. frequencies. This may reflect the large statistical uncertainties affecting pollen accumulation rates (Davis et al., 1984).

In recent sediment samples from Santa Barbara Basin, pollen composition reflects the composition of major plant associations growing nearby (Table 1). Pollen assemblages in sediment deposited over the last $20 \mathrm{yr}$ (e.g., the uppermost sample from Hole 893A: Sample 146-893A-1H-1, 4-6 cm; 0.04 mbsf) (Fig. 5) and samples from box Core SBB 11-19-89 (34 $14.0^{\prime} \mathrm{N}, 120^{\circ} 01^{\prime} \mathrm{W}, 587 \mathrm{~m}$ water depth)

\section{Pollen concentration}

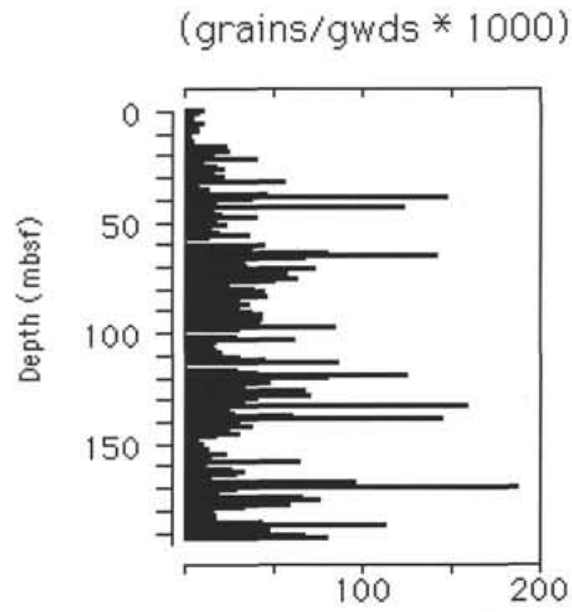

Figure 2. Depth plot of pollen concentration in Hole 893A.

are composed of Quercus, shrub, and herb taxa representative of the present mosaic oak woodland/chaparral/sage scrub communities on shore (L.E. Heusser, unpubl. data). In addition to these, regional taxa that periodically appear in lesser amounts include: Ephedra, Salix, Juglans, Fraxinus, Myrica, Platanus, Sarcobatus, Eriogonum, Pseudotsuga, Abies, Umbelliferae, Cyperaceae, fern spores, Selaginella, Isoetes, and Sphagnum.

Percentages of Quercus and Compositae, excluding Artemisia. (taxa which dominate the upper $23.5 \mathrm{~m}$ of Hole 893A) fluctuate substantially downcore. Major changes in their relative abundance and in that of the other pollen types shown in Figure 5 were used as the basis for defining pollen zones (Table 2). Quercus maxima, accompanied initially by small but significant amounts of Alnus, characterize pollen assemblage zones (PAZs) 9, 5, and 1-and, to a lesser degree, PAZs 5 and $3 \mathrm{c}$. The relative abundance of the Rhamnaceae, Rosaceae, and Anacardiaceae (RRA), Compositae, and Chenopodiaceae display a similar pattern. Beginning with PAZ 9, percentages of Quercus, Compositae, and Chenopodiaceae show an overall upward decrease to PAZ 3a. Peaks of Quercus, Compositae, and Chenopodiaceae, together with abundant TCT, characterize PAZs 5 and 3c.

Conifers (TCT and Pinus) with varying amounts of Artemisia characterize all the other pollen zones (PAZs 10, 8, 6, 4, 3, and 2). In fact, TCT-type pollen dominates most of the record from Hole 893A. Pinus, which is more important in the upper half of the pollen diagram, peaks in PAZs 4, 3b, and 2, and large contributions of Artemisia identify subzones PAZ $10 \mathrm{~b}$ and PAZ $3 \mathrm{c}$.

When plotted vs. age on the Y-axis (Fig. 6), variations in percentages of Quercus, RRA, Compositae, and Chenopodiaceae clearly mirror the classic glacial/interglacial pattern of the last $160 \mathrm{k} . \mathrm{y}$., which is also seen in the $\delta^{18} \mathrm{O}$ variations plotted from comparable sample depths in Hole 893A (Kennett, this volume). OIS-1 and -3 and the substages of OIS-5 (5a, 5c, and 5e) are delineated by maxima in these three pollen groups. Minimal amounts of Quercus, RRA, Compositae, and Chenopodiaceae occur in OIS-2, -4 , and -6 . The nature and timing of changes in Quercus pollen and in the benthic $\delta^{18} \mathrm{O}$ values are remarkably similar. For example, the abrupt increase in both these variables occurs at exactly the same depth at the beginning of OIS-1 and -5e (Fig. 7). The major difference between the pollen and oxygen isotope curves in Figure 7 is the Quercus spike at $\sim 108$ k.y.

Prior to 14 k.y., except for brief intervals (centered at $\sim 52,80$, 108 , and 125 k.y.) TCT pollen types dominate the pollen record from Hole $893 \mathrm{~A}$, although the younger glacial intervals (OIS -2 and -4 , as well as stadials of OIS-3), unlike those $>70$ k.y. (OIS-5b, $-5 \mathrm{~d}$, and 

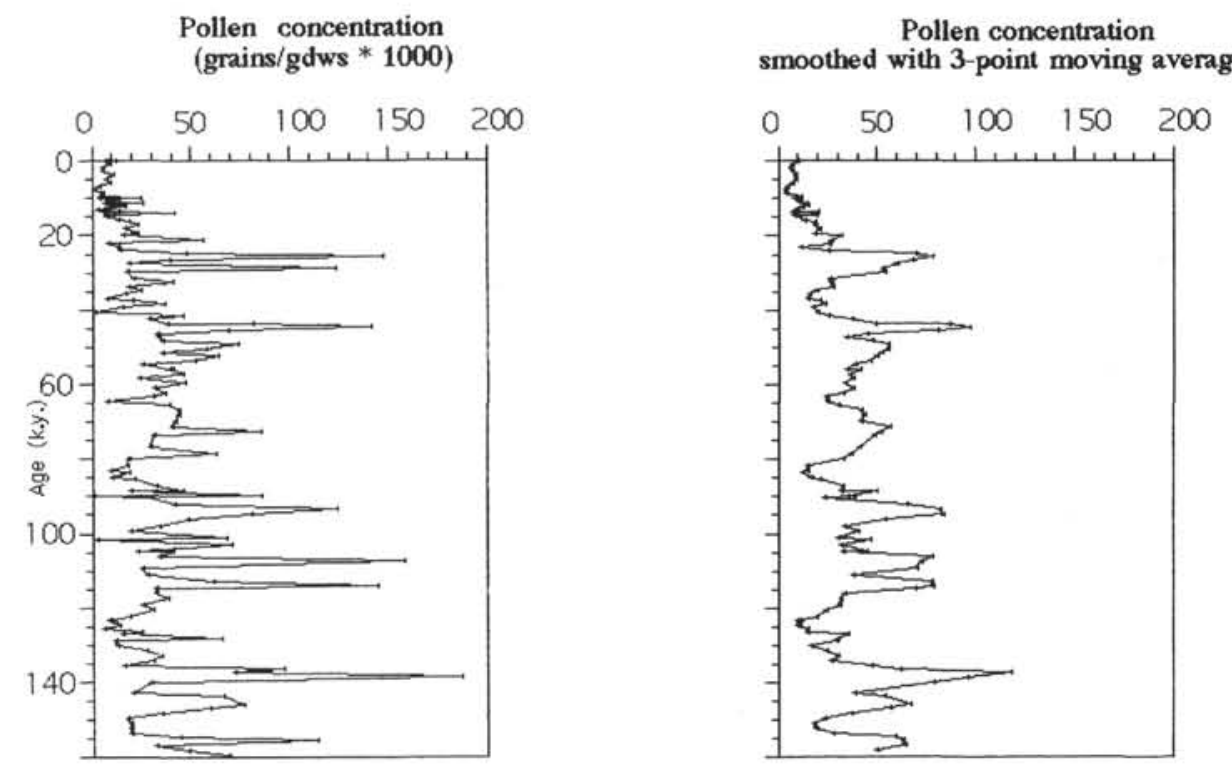

Figure 3. Times series of pollen concentration in Hole 893A. Data on the right were smoothed with a 3-point moving average.

-6), are characterized by substantial amounts of Pinus (Fig. 6). Other conifers present periodically are Tsuga mertensiana (mountain hemlock), Picea, Abies, T. heterophylla, Pseudotsuga, and Sequoia (presumably $S$. sempervirens, coastal redwood).

Because of the length and complexity of the pollen record from Santa Barbara Basin, it is instructive to examine some segments in

\section{Mass accumulation rate pollen}

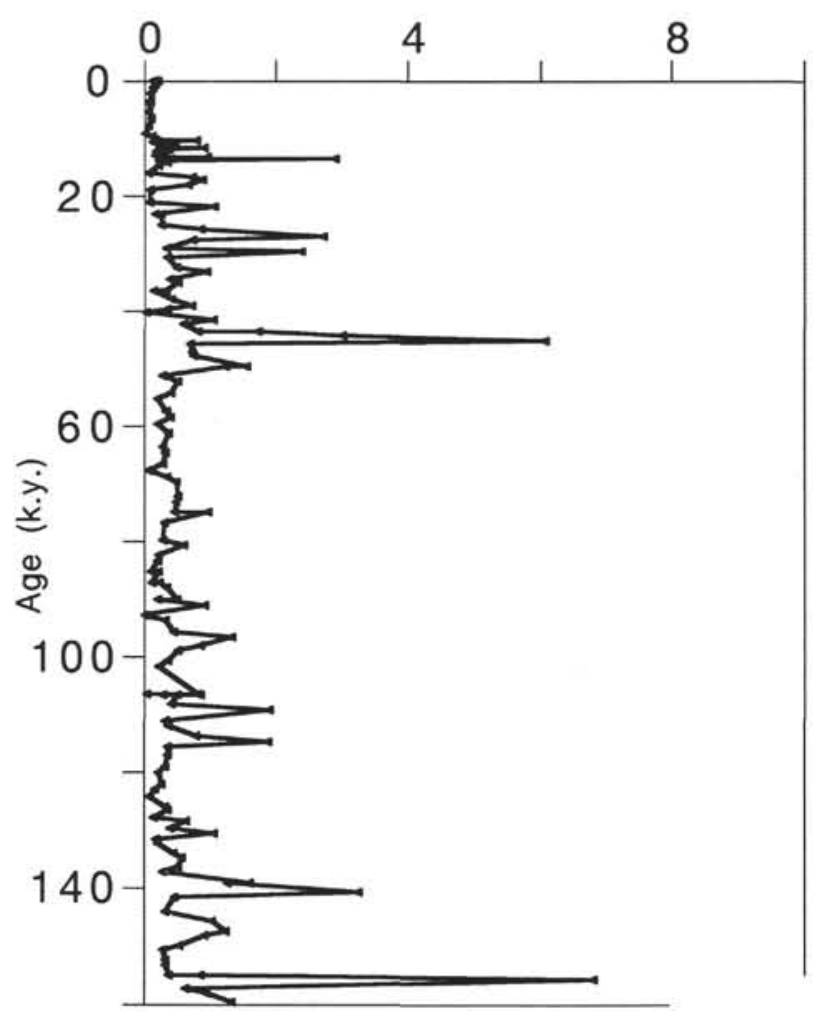

Figure 4. Time series of pollen mass-accumulation rate in Hole 893A. greater detail. The last $30 \mathrm{k.y}$. documents the replacement of gymnosperms, which dominate glacial sediments, by angiosperms (Fig. 8). Between $\sim 30$ and 14 k.y., conifers totally dominate. TCT, accompanied by lesser amounts of Pinus, Artemisia, and Compositae between 30 and 26 k.y. increases to $\sim 80 \%$ at $25 \mathrm{ka}$, and then decreases to $<10 \%$ until 14 ka when a brief 2-k.y. re-expansion occurs. Artemisia and Compositae reach maximum glacial levels at $\sim 18 \mathrm{ka}$. The record of Pinus is quite different. At the end of the last glacial, Pinus rises gradually to peak levels $(\sim 6 \%)$ at $\sim 15 \mathrm{ka}$, abruptly drops to $\sim 10 \%$ at $14 \mathrm{ka}$, and then fluctuates between $<10 \%$ to $40 \%$ for the next 4 k.y. Significant changes in other taxa also occur between 14 and 10 k.y., of which the rise in Quercus from $<5 \%$ to $\sim 40 \%$ is perhaps the most obvious. Lesser increases occur in the Chenopodiaceae and RRA.The rapid shift from Pinus to Quercus prominence at $14 \mathrm{ka}$, followed by a resurgence in TCT pollen types and secondarily of Pinus, is accompanied by a unique increase in Alnus. The timing of these deglacial fluctuations may be correlative with such brief events as the European Younger Dryas. It is interesting to note, however, that the evidence of apparent climatic reversal in the pollen data is not completely synchronous with lithologic changes interpreted as evidence of climatic reversal (Shore-based Scientific Party, 1994).

Between 30 and $70 \mathrm{k.y}$., the pollen assemblage is dominated by inaperturate conifers (TCT values average 54\%) (Fig. 9). Pinus, which is most abundant between $\sim 44$ and 30 k.y., exhibits a brief expansion centered at $\sim 60 \mathrm{ka}$. This precedes small increases in Quercus (to $<10 \%$ ) between $\sim 58$ and 50 k.y. The beginning of OIS-3 is also marked by higher values of shrubs and herbs (RRA, Compositae, Artemisia, and Chenopodiaceae). Alnus is absent, except for two samples where it is present in trace amounts.

OIS-5 is characterized by large amounts of Quercus, which reach Holocene values at $\sim 124 \mathrm{ka}$ and again between $\sim 106$ and $\sim 108 \mathrm{ka}$. A minor increase occurs $\sim 84$ ka (Fig. 10). The Quercus assemblages include small but consistent amounts of Alnus that are highest at the base of OIS-5 (substage 5e). As in the Holocene, Pinus, which increases prior to Quercus, is minimal during the last interglacial. The replacement of gymnosperms by angiosperms at the beginning of the last interglacial appears to be less abrupt than at the beginning of the Holocene; however, this may be an artifact of our sampling interval and time scale. The last interglacial (OIS-5e) also differs subtly from the Holocene with higher TCT percentages and with slightly lower percentages of Alnus and Artemisia. 


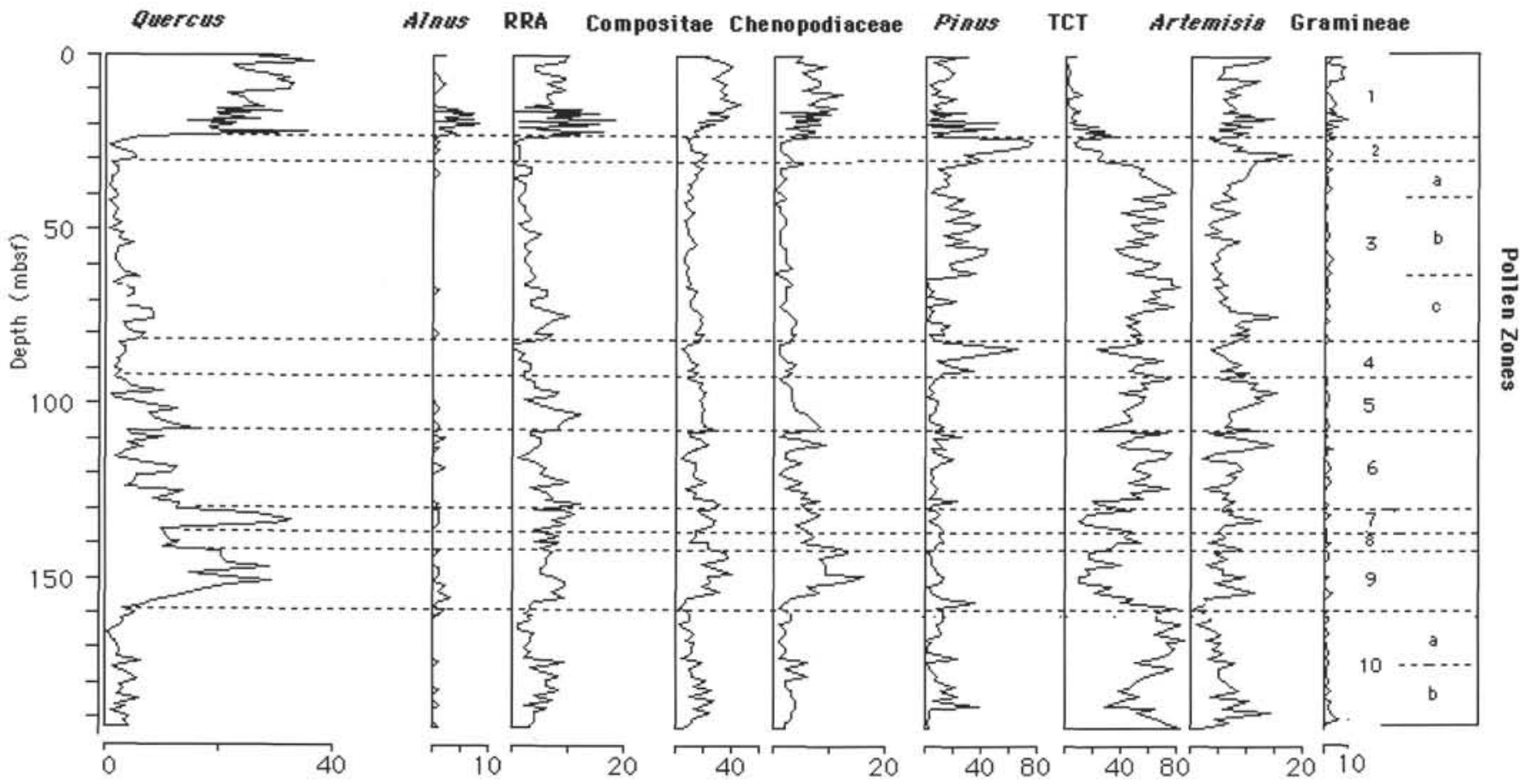

Figure 5. Depth plot of the relative abundance (\%) of selected pollen types from Hole 893A. Pollen zones (Table 2) are shown on the right.

Table 2. Preliminary pollen zones from Hole 893A.

\begin{tabular}{llcc}
\hline & Pollen zone & $\begin{array}{c}\text { Depth } \\
\text { (mbsf) }\end{array}$ & $\begin{array}{c}\text { Age } \\
\text { (k.y.) }\end{array}$ \\
\hline 1 & Quercus & $0-23.5$ & $0-14.9$ \\
2 & Pimus & $23.5-31$ & $14.9-20$ \\
3 & TCT & $31-81$ & $20-56$ \\
$3 \mathrm{a}$ & TCT Artemisia & $31-40$ & $20-26$ \\
$3 \mathrm{~b}$ & TCT-Pinus & $40-64$ & $26-44$ \\
$3 \mathrm{c}$ & TCT Quercus & $64-81$ & $44-56$ \\
4 & Pimus-TCT & $81-95$ & $56-70$ \\
5 & Quercus & $95-109$ & $70-84$ \\
6 & TCT & $109-130$ & $84-104$ \\
7 & Quercus & $130-136$ & $104-110$ \\
8 & Quercus-TCT & $136-141$ & $110-116$ \\
9 & Quercus & $141-160$ & $116-128$ \\
10 & TCT & $160-194$ & $128-161$ \\
$10 \mathrm{a}$ & TCT & $160-183$ & $128-144$ \\
$10 \mathrm{~b}$ & TCT-Artemisia & $183-194$ & $144-161$ \\
\hline
\end{tabular}

Q-mode factor analysis of the pollen data from Hole 893A (17 taxa, 159 samples) provides added insight into the structure of the data. Five factors, identified by the names of the diagnostic taxa in each assemblage, capture $99 \%$ of the variability in the raw pollen counts (Appendixes A and B; Fig. 11). In the TCT factor, TCT pollen with RRA, Artemisia, Chenopodiaceae, and Compositae of secondary importance, is segregated from other taxa. One source of TCT pollen in this factor is probably Juniperus. Juniper, which also occurs in small, widely separated stands in oak woodland and chaparral of the Coast Range (Griffin, 1977; Hanes, 1977), is present on lower mountain slopes in western Santa Barbara County (Vasek and Thorne, 1977) and is widely distributed to the east. It is possible that this factor represents Juniperus communities not unlike those now distributed in the Great Basin (Anderson and Davis, 1988; Hevly et al., 1965; Leopold, 1967; Solomon and Silkworth, 1986). This factor may also represent the expansion of cypress, which now occurs in small, disjunct communities scattered along the California coast. One of the most widely distributed, $C$. sargentii, is found on Zaca Peak in Santa

Age
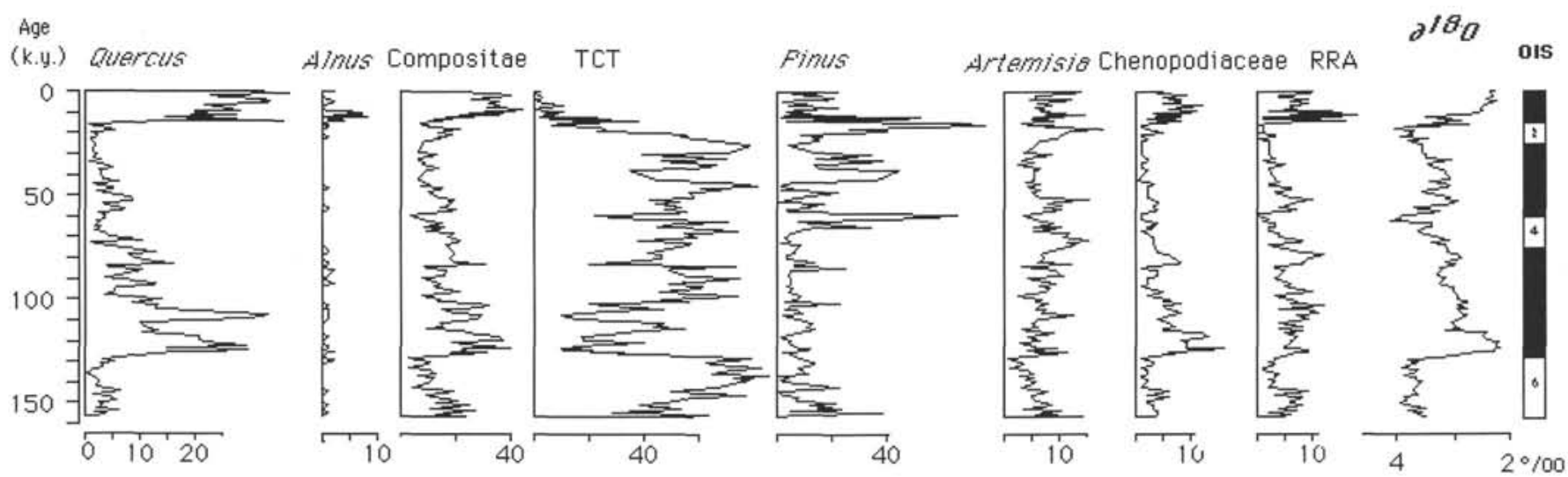

Figure 6. Time series of the relative abundance (\%) of selected pollen types from Hole 893A. The $\delta^{1 \times} \mathrm{O}$ record and oxygen isotope stage (OIS) zonation shown on the right are from Kennett (this volume). 

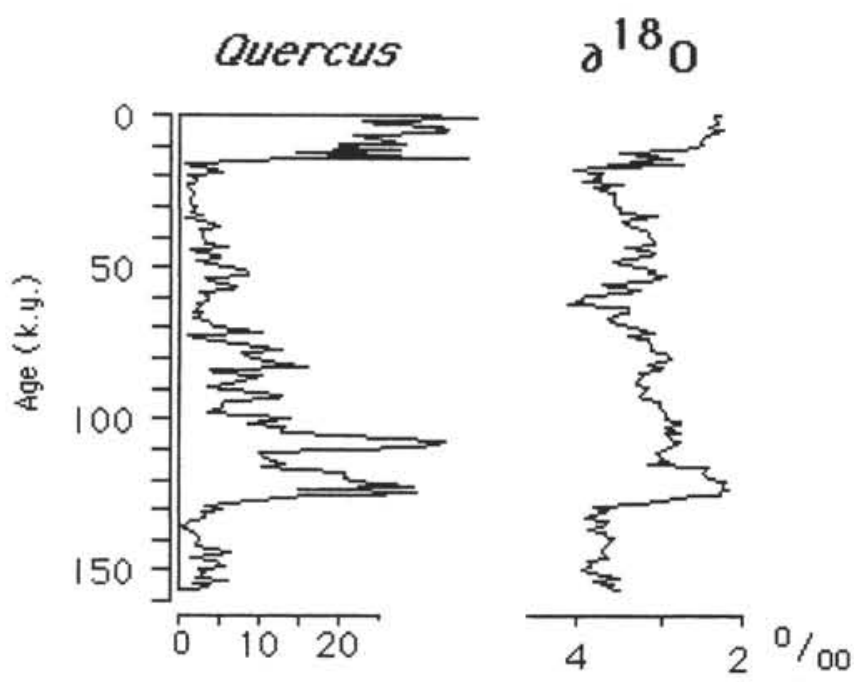

Figure 7. Time series of the relative abundance (\%) of Quercus (oak) from Hole $893 \mathrm{~A}$ plotted with the $\delta^{18} \mathrm{O}$ record from the same sample intervals on the right (Kennett, this volume).

Barbara County, 1323 m above sea level (Thorne, 1977; Vogl et al., 1977; Mensing, 1993). The negative association between inaperturate conifer pollen (TCT) and Pinus, however, suggests that this factor may not represent communities like southern California closedcone pine and cypress stands, upper montane and subalpine conifer forests, piñon-juniper woodland, or any plant community in which
Juniperus, Libocedrus, or Cupressus is associated with Pinus (Heusser, 1960; Leopold, 1967; Thorne, 1977).

The Quercus-Compositae factor groups oak with all pollen types except TCT and Abies. This factor is interpreted as representative of present-day southern California oak associations, such as lowland oak woodlands, oak-dominated chaparral, oak woodland and grassland, as well as lower and mid-montane woodlands in which oak is prominent (Barbour and Major, 1977). These first two factors account for $86 \%$ of the original variability.

In the third factor, which accounts for $12 \%$ of the total variance, Pinus is positively associated with conifers (TCT, Picea, Tsuga, and Abies), shrubs and herbs (Artemisia, Ephedra, Gramineae) and is negatively related to Quercus, Alnus, RRA, Compositae, and Chenopodiaceae. This factor is interpreted as representing pine-conifer forests in which oak is absent and herbs are not well developedsouthern California communities such as the upper montane and subalpine coniferous forests of the eastern Transverse Ranges, or possibly coastal closed-cone pine and cypress (Thorne, 1977; Vogl et al., 1977). In this factor, as in the TCT factor, the negative relation between Quercus and Pinus precludes interpreting this component as a pine oak woodland, or as piñon-juniper foothill woodland of Baja, California, in which oak is present (Leopold, 1950). The minimal representation of Picea, Abies, and Tsuga, and the absence of Sequoia suggest that this factor is in no way analogous with present-day mesic lowland conifer forests to the north (e.g., Pacific Coastal Forest of the north California and Oregon coast (Barbour and Major, 1977).

Although the remaining two factors account for less than $1 \%$ of the variability, they are of interest because they isolate three ecologically interesting communities: riparian, sage scrub/chaparral, and halophytic associations. In the Alnus factor, Alnus, along with Picea,
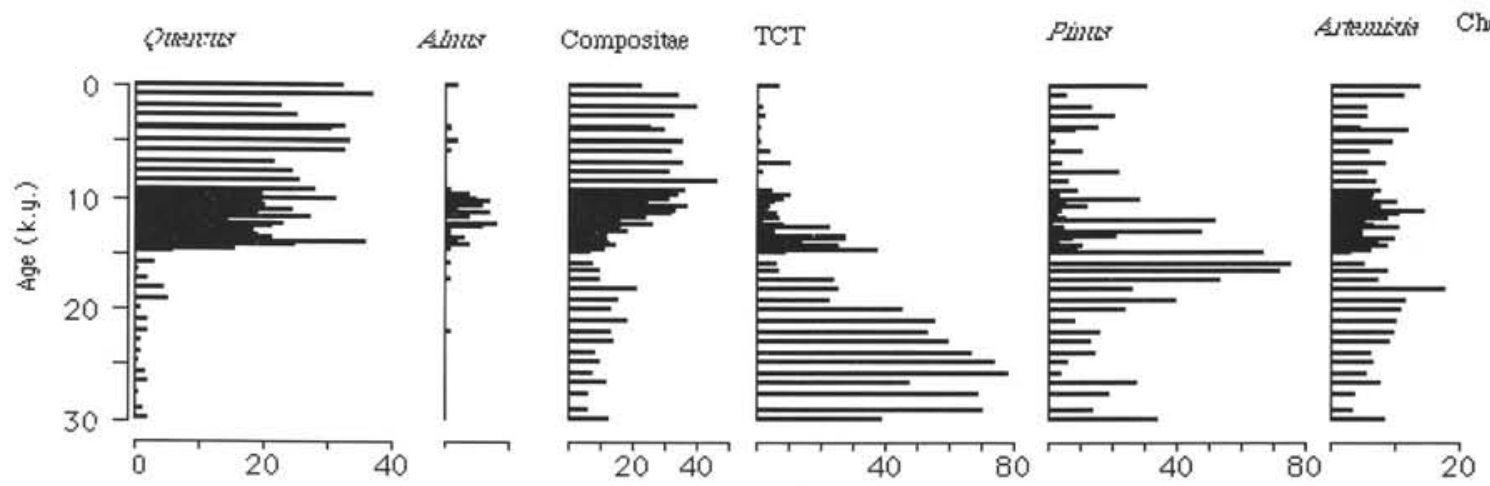

Chenopodiaceae RRA

Figure 8. Plot of the relative abundance (\%) of selected pollen types from upper $30 \mathrm{k.y}$. of record from Hole 893A. The darker plot reflects denser sampling between $\sim 10$ and 15 k.y.

Quercus Alnus Compositae TCT

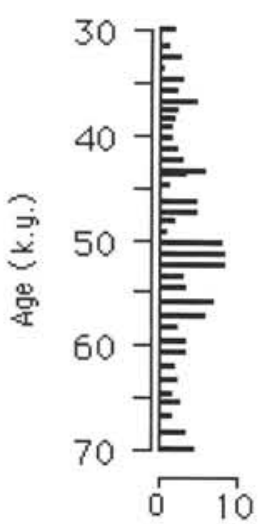

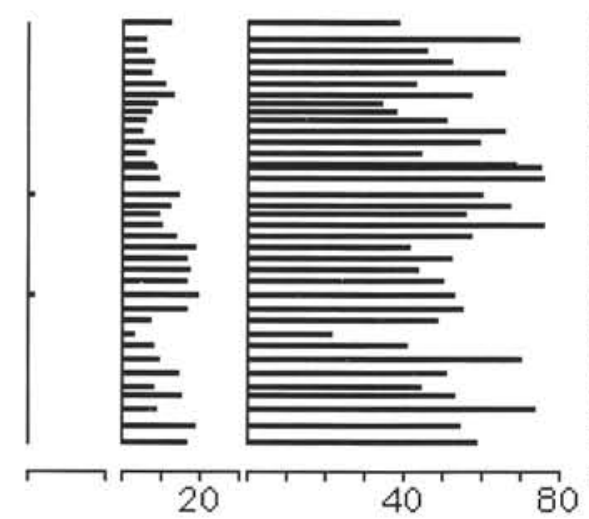

Finus

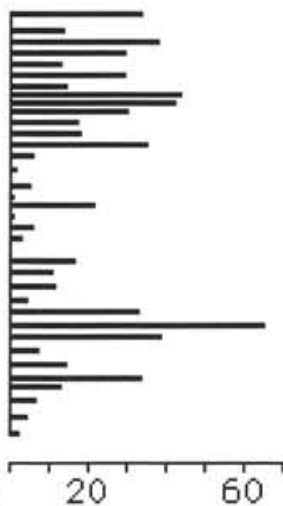

Artemisis Chenopodiaceae RRA

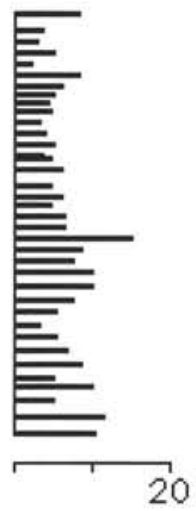

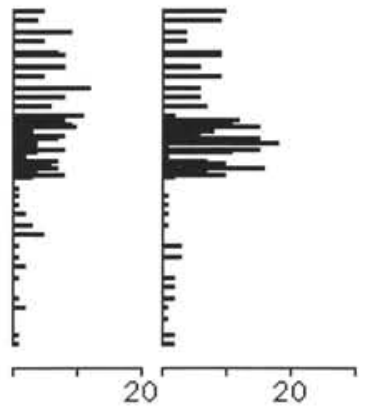

Figure 9. Plot of the relative abundance (\%) of selected pollen types from Hole 893A during the last full glacial interval between 30 and $70 \mathrm{k.y}$. 

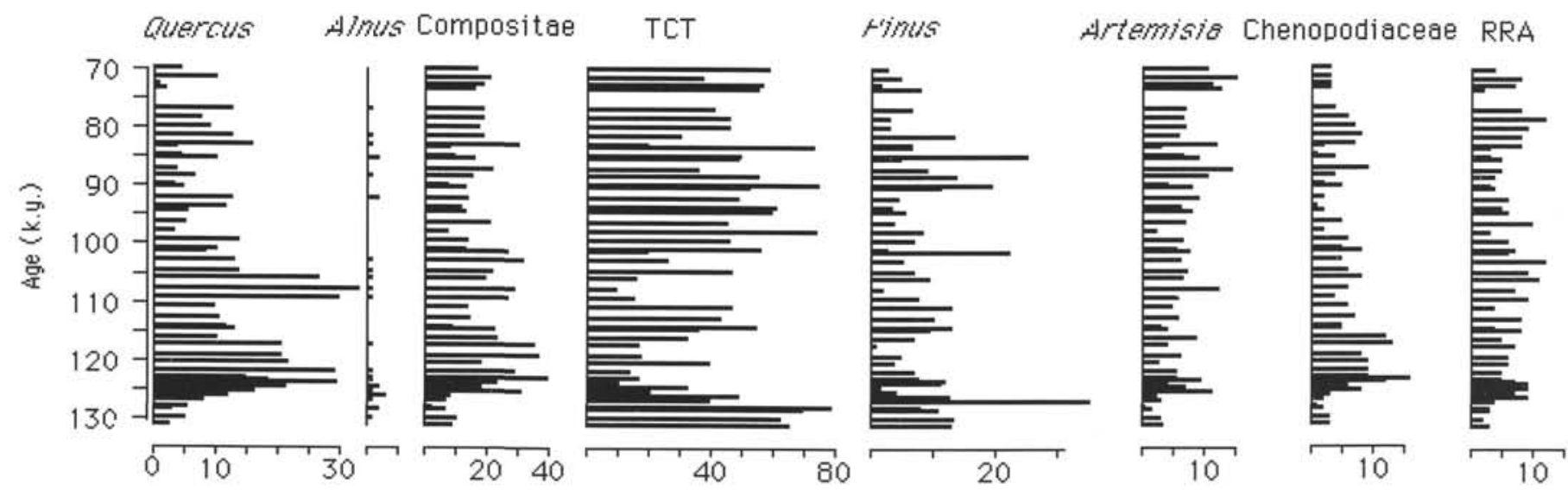

Figure 10. Plot of the relative abundance $(\%)$ of selected pollen types from Hole $893 \mathrm{~A}$ between 70 and 130 k.y.

Tsuga, Pinus, and RRA, is negatively related to Quercus and TCT pollen types. The association of alder (presumably A. rhombifolia which now grows along streams in southern California) with more mesic types such as Picea, Tsuga, and Pinus, suggests that this factor might be an indicator of precipitation/runoff. The composition of the Alnus factor resembles present-day surface samples from areas with greater rainfall than southern California (e.g., western Oregon; Heusser, C.J., 1978) or northern California coastal forests in which Sequoia is not present (Heusser, 1988). The latter possibility suggests that the Alnus assemblage, or any of the fossil pollen assemblages from Hole $893 \mathrm{~A}$ for that matter, may not have exact modern pollen or vegetation analogues.

The fifth factor separates Chenopodiaceae pollen, which is positively associated with Pinus, Quercus, and TCT, from Artemisia and Ephedra. This factor identifies a dichotomy between coastal southern California communities-halophytic communities in which chenopods are well developed (e.g., salt marshes and beach strands) and communities in which Artemisia (sage) is prominent and Pinus, Quercus, and Juniperus are absent (possibly extensive chaparral and/ or coastal sage scrub far from any trees) (Mooney, 1977; Mudie and Byrne, 1980).

\section{DISCUSSION}

Pollen concentration in Santa Barbara Basin is up to four times as high as in a basin farther offshore (Tanner Basin, $32^{\circ} 54.92^{\prime} \mathrm{N}$, $119^{\circ} 44.23^{\prime} \mathrm{W} ; 1475 \mathrm{mbsf}$ ), and about 10 times the pollen concentration of marine sediments deposited elsewhere along the northeast $\mathrm{Pa}$ cific coast (Cross et al., 1966; Heusser and Balsam, 1977; L.E. Heusser, unpubl. data). The large quantity of pollen in sediments of Santa Barbara Basin, amounts that are comparable to the highest marine pollen concentrations reported elsewhere in the world (e.g., the Black Sea and modern and fossil deltaic environments; Traverse, 1988), is related to the proximity of the source areas of pollen, the unusually high terrigenous (including pollen) sedimentation rates, and the excellent pollen preservation in sediments deposited under the anoxic to suboxic bottom waters of Santa Barbara Basin.

The relative importance of fluvial pollen transport in marine pollen sedimentation elsewhere on the Pacific coast of North America (Heusser and Balsam, 1977) implies that rivers are a primary factor in pollen sedimentation in Santa Barbara Basin. Previous analyses showed that the Santa Clara and Ventura rivers carried surprisingly large amounts of pollen (Heusser, L.E., 1978), and pollen analysis of monthly samples from sediment traps off northern California and southern Oregon showed that seasonal variations in pollen concentration correlated more with seasonal variations in precipitation/runoff than with pollen production and initial aeolian dispersal (Heusser, 1988). Therefore, the large amounts of pollen in Santa Barbara Basin are assumed to be related to the extremely high flux of pollen-bearing terrigenous sediment delivered by winter runoff from the Ventura, Santa Clara, and possibly the Santa Ynez Rivers (Soutar and Crill, 1977; Gardner and Dartnell, this volume). This interpretation is supported by the comparatively high percentages of riparian taxa (principally Alnus) in nonlaminated sediments of Hole 893A (Fig. 8) that are attributed to increased precipitation/runoff (Rack et al., this volume), and by the increased importance of the Alnus factor between $\sim 14$ and 10 ka (Fig. 11), a time when flow rates of the Santa Ynez River were higher than present (Morgan et al., 1994) and when stream aggradation increased in the Transverse Ranges (Weldon, 1983) and central coastal California (Rypins et al., 1989).

The preliminary results of pollen analyses of varves deposited in Santa Barbara Basin between 1989 and 1974, however, show little correlation between annual pollen concentration and precipitation in Santa Barbara or runoff from the Ventura and Santa Clara rivers (Schimmelmann and Tegner, 1992; C. Lange and L. Heusser, unpubl. data). In addition, variability in pollen concentration and accumulation rates does not appear to correlate with patterns of other sedimentary parameters from Hole $893 \mathrm{~A}$ (\% $\mathrm{C}$ organic, magnetic susceptibility, and sediment flux; Gardner and Dartnell, this volume; Rack et al., this volume) that are also genetically related to precipitation/runoff. This apparent lack of correspondence may, at least in part, reflect the polygenetic origin of all the sedimentary components, as well as the complex relation between pollen productivity, transport, and deposition (Solomon, 1972; Solomon and Hayes, 1972; Solomon and Silkworth, 1986).

Undoubtedly, aeolian transport and marine currents also play a role in pollen sedimentation in Santa Barbara Basin (Heusser, L.E., 1978). Chenopod pollen from salt marshes bordering Santa Barbara Channel may be carried to the shelf both by wind and tidal flux. Winds associated with winter and early spring storms may carry substantial amounts of pollen offshore from those plants that bloom early in the year in southern California (e.g., Alnus, Juniperus, and Quercus), and less-frequent summer storms may transport shrub and herb pollen produced at that time of year (Karau, 1968). Unfortunately, data relating eolian dispersal of pollen from modern southern California plant communities are lacking. The closest most relevant studies (from the Sierra Nevada and from the Mojave and Sonoran deserts) show that contemporary pollen rain can be used to distinguish vegetation types such as oak grassland/woodland and chaparral, montane and subalpine forests, and desert communities (Solomon and Hayes, 1972; Anderson and Davis, 1988; Leopold, 1967). Studies of atmospheric pollen accumulation in montane regions elsewhere show that eolian transport accounts for $\sim 1 / 5$ of pollen influx (Fall, 1992).

Once in marine waters, rapid deposition of pollen, like other terrigenous particles, is suggested by the similarity in the composition and concentration of pollen in sediment traps moored at different depths in the same location, by the preservation of seasonal variations 

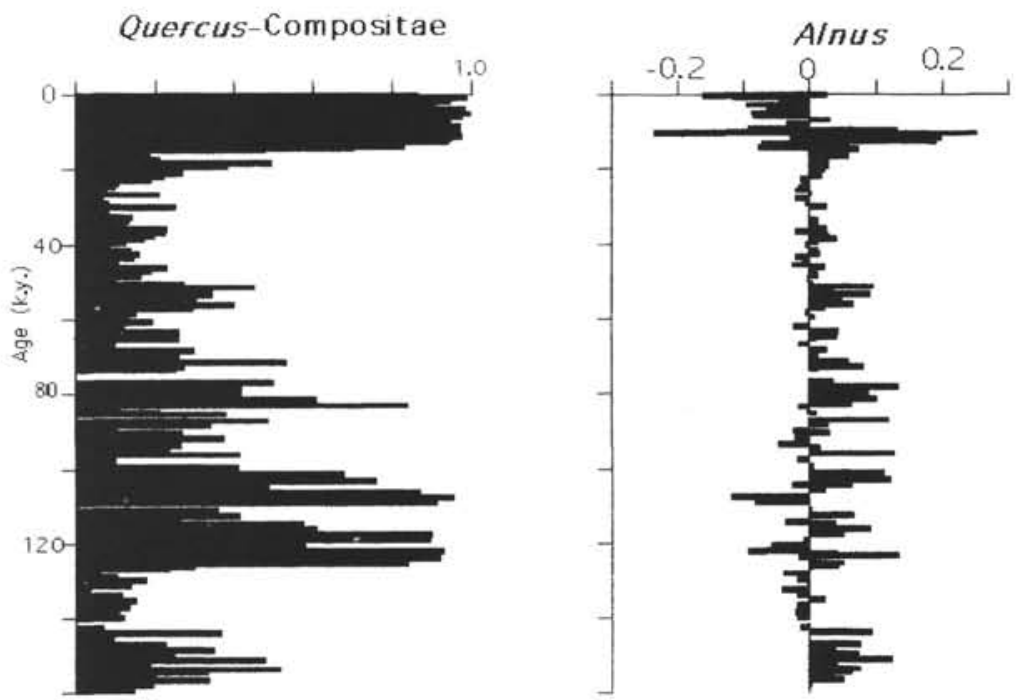

Figure 11. Time series of pollen assemblages (factors) from Hole 893A.

in annual pollen assemblages, and by the similarity between the geographic distribution of marine pollen assemblages and terrestrial vegetation formations onshore (Heusser, 1988; Heusser and Balsam, 1977; L.E. Heusser, unpubl. data). For example, pollen assemblages deposited in Santa Barbara Basin since the nineteenth century include pollen from alien plant species that were introduced in coastal southern California during that time (e.g., Erodium, Eucalyptus and Acacia) (Mensing, 1993; C. Lange and L. Heusser, unpubl. data).

Using the principle of least astonishment, interpretation of the fossil pollen data from Hole $893 \mathrm{~A}$ is based on the assumption that fossil pollen in the sediment deposited in Santa Barbara Basin mirrors the vegetation of coastal southern California in the same manner as recent marine pollen records reflect onshore vegetation (Gardner et al., 1988; Mensing, 1993). Although there are no pollen data from the southern coast of California with which the entire 160-k.y. pollen record from Santa Barbara Basin can be compared, comparison of Holocene pollen data from Santa Barbara Basin (the upper $20 \mathrm{~m}$ of Hole 893A and Core Y71-10-117P; Heusser, L.E., 1978) with terrestrial pollen records of comparable duration (six relatively short records $\sim \leq 12$ k.y.; Peterson, 1980; Davis, 1992; Cole and Liu, 1994; Mensing, 1993; Morgan et al., 1994; West, 1994) indicates that Holocene marine pollen data from Santa Barbara Basin show the same major vegetational changes seen in the onshore pollen data.

What is surprising is that variations in the relative abundance of the most abundant pollen types in the cores from Hole 893A in Santa Barbara Basin are generally similar to variations in the relative abundance of the same pollen types in cores taken in the North Coast Range of California (Adam, 1988; Sims et al., 1981), an ecologically and climatologically very different area (Fig. 12). The oak curves from the 197-m Hole 893A record from arid, coastal southern California and the $115-\mathrm{m}$ record from Clear Lake, a more mesic site on the leeward side of the north California Coast Range, appear similar in amplitude and length (Adam et al., 1981). The most apparent difference between the southern and northern California oak pollen records plotted in the depth domain is the 3-point peak centered $\sim 133$ mbsf in Hole 893A. Precise comparison of these two curves in the time domain is problematic due to differences in ${ }^{14} \mathrm{C}$ calibration in the younger parts of the records, and to the subjective age models usedof necessity - in the older parts of the Clear Lake record (compare the age assignment of $64,000 \mathrm{ka}$ [Adam and West, 1983] at $\sim 72 \mathrm{~m}$ in core $\mathrm{Cl}-4$ with the radiocarbon date of $29,300 \pm 390$ for the same interval [Adam et al., 1981]). It would appear that the basal oak maximum in core $\mathrm{Cl}-4$ (pollen zone I-2; Adam et al., 1981) corresponds with the basal oak maximum in Hole 893A (PAZ 9) which was deposited during OIS-5e (Fig. 7).

Downcore variations in the relative abundance of oak pollen in Hole 893A (Figs. 5 and 7) imply major changes in the abundance and distribution of open oak woodlands, woodland or scrub oak chaparral, and/or coastal scrub in south coastal California over the past 160 k.y. Variations in the importance of the Quercus factor (Fig. 11) also imply optimal development of oak-dominated communities during interglacials (OIS-1 and -5e) and minimal representation during glacial maxima (OIS-2 and -6). Subtle differences in the percentages of the principal taxa in the interglacial Quercus assemblages (PAZs 1 and 9; Fig. 5), for example the higher percent of Chenopodiaceae and TCT in PAZ 9, suggest that the mosaic of oak-dominated plant communities now growing in the Santa Barbara region is a postglacial development. The oak pollen assemblage deposited between $\sim 128$ and $\sim 116$ k.y. resembles modern pollen rain from oak woodland in the foothills of the central Sierra Nevada (Anderson and Davis, 1988) and is also suggestive of Pliocene Quercus-Juniperus woodland (Ax-

ODP 893A

Clear Lake
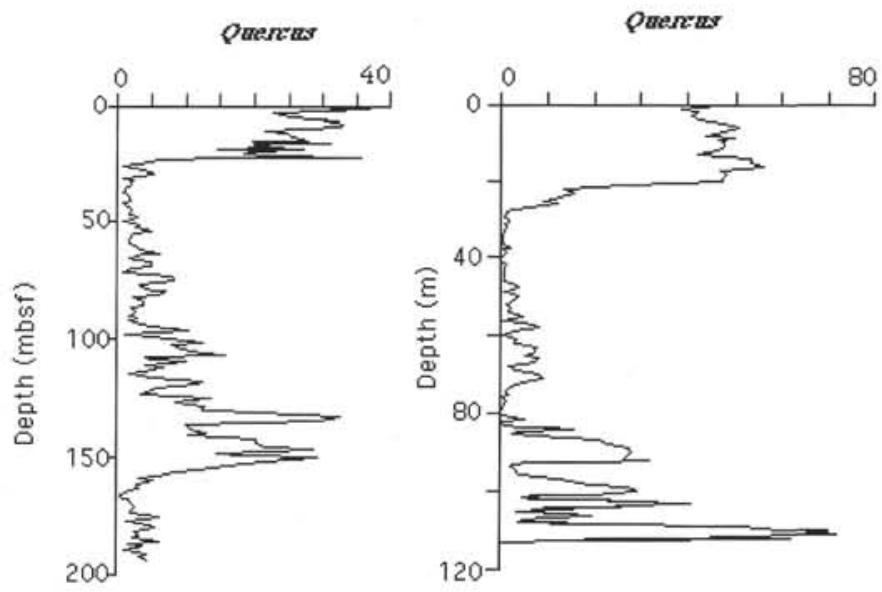

Figure 12. Depth plots of the relative abundance (\%) of Quercus in Hole 893A and in Clear Lake (Adam et al., 1981). 

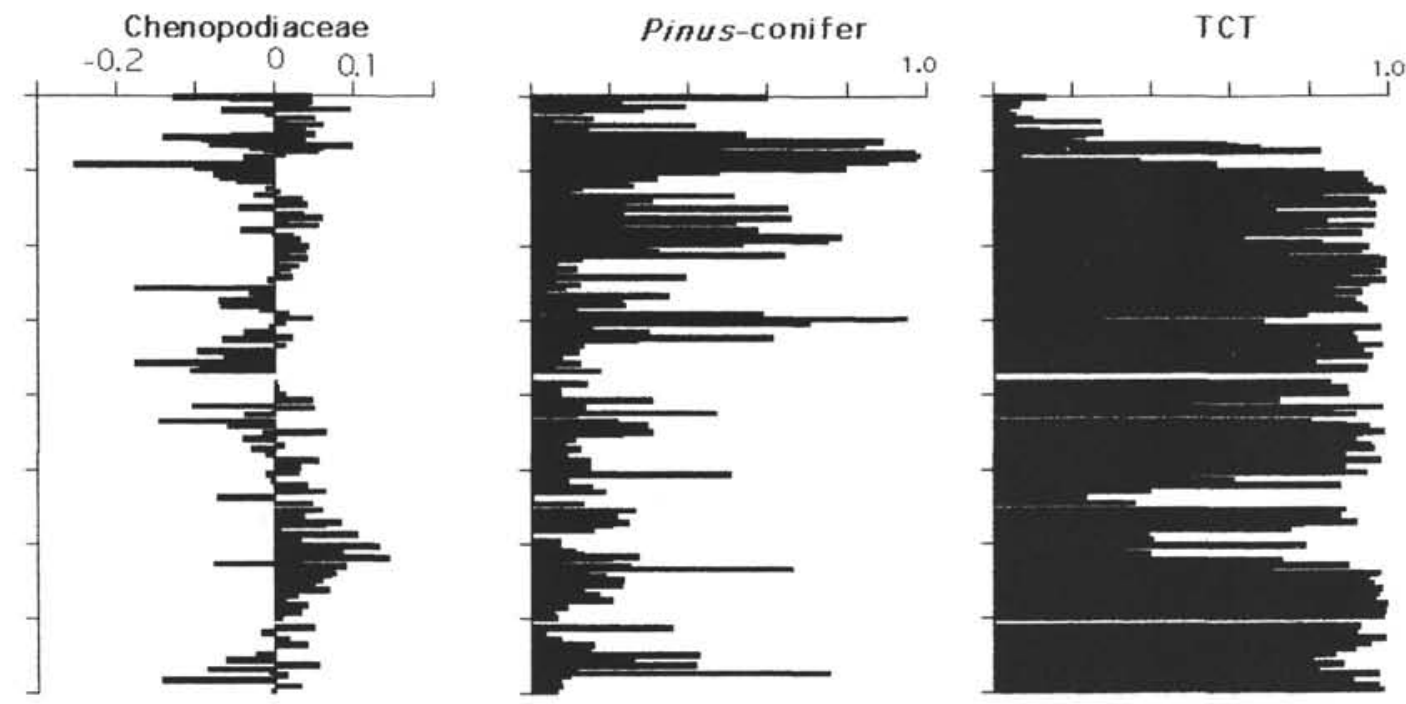

Figure 11 (continued).

elrod, 1977). Other paleobotanical evidence from California also is interpreted as evidence of the relative youth of present oak woodland taxa (Q. agrifolia and Q. engelmannii) (Axelrod, 1977). Glacial/interglacial fluctuations in the value of positive loadings of the chenopod factor (Fig. 11) vary in the same general manner as global sea level (e.g., peaking during interglacial and interstadial intervals). One interpretation of the variations in this factor is that the development of coastal salt marshes near Santa Barbara Basin is positively related to regional sea level changes (Martin and Gray, 1962: Macdonald, 1977). It is also possible that some of the chenopod pollen in this factor reflects long-distance transport from areas with high soil salinity, (e.g., salt pans in eastern California or Baja California; Benson and Thompson, 1987; Leopold, 1967), and that variations in the chenopod factor also reflect the expansion and contraction of saline habitats due to changes in aridity.

Glacial vegetation near Santa Barbara Basin and in coeval sediments deposited off California between $\sim 32^{\circ} \mathrm{N}$ and $\sim 36^{\circ} \mathrm{N}$ (Heusser, 1994 ) is reconstructed as conifer woodland in which Quercus was sparse, and in which representatives of lowland Pacific coastal forest (e.g., $T$. heterophylla, S. sempervirens, and $P$. sitchensis) were essentially absent. Interpreting the most prominent coniferous assemblage as Juniperus-dominated implies widespread distribution of communities like those now found in montane-juniper woodlands in the Transverse Ranges. This interpretation would concur with similar altitudinal depression of vegetation postulated elsewhere in the southwest (Axelrod, 1977), and with the expansion of juniper in the interior (Leopold, 1967; Van Devender et al., 1987). Montane coniferous communities (mid-montane conifer forest or lower montane woodlands) would also have been present if some of the inaperturate conifer pollen is ascribed to Libocedrus decurrens, which was present in the Santa Cruz Mountains during "moister phases of the Quaternary" (Axelrod, 1977).

Although Juniperus definitely was growing on the southern California coastal plain during the Pleistocene (the Rancho La Brea macroflora; Axelrod, 1977), it is also probable that Cupressus formed a part of coastal vegetation during the last glacial. The present-day disjunct spatial distribution of cypress-isolated small stands scattered along the California coast - has been interpreted as evidence of widespread distribution prior to the Holocene (Vogl et al., 1977).

The periodic prominence of Pinus-dominated vegetation suggests altitudinal and possible latitudinal expansion of upper montane coniferous forest communities similar to those now growing above $\sim 1600$ $m$ in the Transverse Ranges during glacial intervals of the past 160 k.y. Another possibility is that closed-cone pine and cypress stands, now restricted to scattered small groves associated with chaparral and foothill woodland communities in southern California, formed part of the southern California pine-dominated glacial assemblages. Both interpretations of the Pinus component from Hole 893A, and from marine cores taken elsewhere off the southern California coast (L.E. Heusser, unpubl. data), concur with previous reconstructions of Pleistocene vegetation from other paleobotanical evidence (Axelrod, 1977; West, 1994).

The relative abundance of herbs and shrubs represented by nonarboreal pollen (Fig. 13), shows glacial/interglacial modulations that are even more similar to those of the oxygen isotope curve than those of Quercus (Fig. 7). Open vegetation communities, such as chaparral, sage, oak scrub, and woodland, are best developed during interglacials (OIS-1 and $-5 \mathrm{e}$ ), as are salt marshes with Chenopodiaceae (Mudie, 1975: Figs. 5 and 11). In arid southern California, as in arid

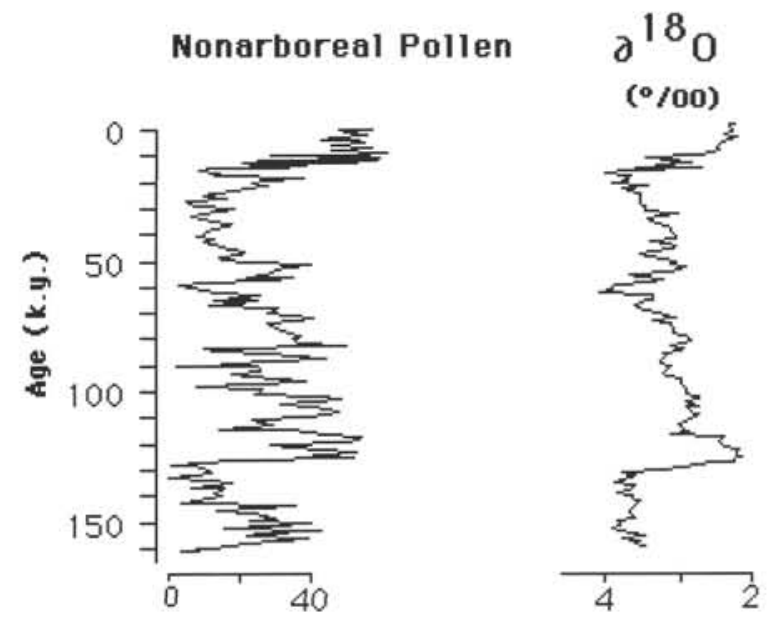

Figure 13. Plot of the relative abundance $(\%)$ of nonarboreal pollen types and $\delta^{18} \mathrm{O}$ from Hole $893 \mathrm{~A}$. The sum of nonarboreal types includes Compositae, Gramineae, Cyperaceae, and other minor herbaceous taxa (Kennett, this volume). 
northern Chile (Heusser, 1983), the relative abundance of nonarboreal pollen during the last glacial cycle is the reverse of nonarboreal abundance in pollen diagrams from temperate regions with more abundant and evenly distributed rainfall (e.g., Washington, France, and New Zealand; Woillard, 1978; Heusser and Heusser, 1990; Heusser and van de Geer, 1994).

The meager amount of Gramineae in the pollen record prior to the last $\sim 14$ ka (Fig. 5) does not appear to support extensive grassland or grassy oak savannas near Santa Barbara Basin. Minimal amounts of nonarboreal pollen $(\sim \leq 10 \%)$ and the limited amount of total variance explained by the shrub- and herb-dominated factor in glacial intervals (e.g., OIS-4 and -6) suggest that glacial vegetation may have been more like closed forest than open woodland.

Fire has undoubtedly played a role in the vegetation dynamics of southern California during the last glacial cycle. Fire is, and has been, a significant factor in the shifting landscape mosaic of lowland biomes, and in the composition of montane yellow pine and juniper forests, in which suppression of fire in recent decades has encouraged the expansion of conifers, commonly at the expense of oak (e.g., $\mathrm{Li}$ bocedrus in mid-montane conifer forest, and Pinus in oak woodland) (Barbour and Major, 1977; Callaway and Davis, 1993; Mensing, 1993). In fire-adapted communities, such as coastal sage scrub, chaparral, oak woodlands, and closed-cone pine and cypress, seed release, germination, and seedling establishment of many species are enhanced by fire. Charcoal fragments were noted in all samples (L.E. Heusser, unpubl. data); therefore, it seems probable that at least some of the changes in the vegetation reflected in the pollen record from Hole $893 \mathrm{~A}$ were fire-related. The analyses of charcoal in recent Santa Barbara sediments (Byrne et al., 1977; Mensing, 1993) have shown some interesting correlations between charcoal and large fires in the adjacent Coast Ranges of southern California. Between 730 and 1505 $\mathrm{AD}$ and 1931-1970 AD, Byrne (Byrne et al., 1977) found a strong correlation between large charcoal fragments and conflagration fires within $50 \mathrm{~km}$ of the Santa Barbara Basin sediments. Although fire frequency in the last 10 k.y. may, at least in part, reflect human activity in southern California, records from other arid environments that are $\geq 40$ k.y. suggest a correspondence between charcoal frequency and effective rainfall (Singh et al., 1981; Heusser, 1983). The role of fire in the vegetational landscape near Santa Barbara Basin presumably is also linked to climatic changes of the last 160 k.y.

The regional and temporal scale of changes in the vegetation of south coastal California inferred from the pollen data from Hole $893 \mathrm{~A}$, corroborated by other marine and terrestrial floral data, implies climatic forcing. Temperature is often the major factor determining plant distribution, and in California, the mean annual temperature amplitude (the warmest month minus the coldest month) is regarded as an important factor in the distribution of southern oak (Q. agrifolia) woodland (Barbour, 1988). Although mean annual temperatures of oak woodlands in California are not significantly different $\left(\sim 16^{\circ} \mathrm{C}\right)$, the mean monthly temperature range $\left(17^{\circ} \mathrm{C}-11^{\circ} \mathrm{C}=\right.$ $6^{\circ} \mathrm{C}$ ) of southern California lowland oak communities is far less than the $\sim 19^{\circ} \mathrm{C}$ annual temperature amplitude of oak $(Q$. douglasii) woodland in northern California (Elford, 1974; Barbour, 1988). In the Santa Barbara region, above the fog belt and away from the moderating influence of the ocean waters, equability (mean annual temperature amplitude) decreases, and the annual range of temperature doubles to $\sim 13^{\circ} \mathrm{C}$ in the coniferous forests of the Transverse Range (Elford, 1974).

The virtual absence of oak pollen (both in relative and "absolute" abundance) in glacial sediments implies that mean annual temperatures were $<\sim 16^{\circ} \mathrm{C}$ (the mean annual temperature of oak woodlands in California), and that the mean monthly temperature range in coastal southern California increased substantially, probably due to lower winter temperatures. A substantial increase in annual temperature amplitude or equability and a concomitant decrease in mean annual temperature would also be implied if the coniferous pollen assemblages that dominated glacials intervals were derived from montane vegetation. During the last glacial, mean annual temperatures inferred from the expansion of montane conifers may have been as low as $\sim 5^{\circ} \mathrm{C}$ (Barbour, 1988), temperatures that would be consistent with the development of glaciers in the San Bernardino Mountains of southern California (Sharp et al., 1959) and with sea-surface temperature estimates in Santa Barbara Basin (CLIMAP Project Members, 1981). Farther north in the Coast Range, full-glacial temperatures of $\sim 7^{\circ}$ to $8^{\circ} \mathrm{C}$ less than present were calculated using a linear relation between elevation and oak (oak + pine) pollen ratios from Clear Lake, California (Adam and West, 1983). Elsewhere in the southwestern United States, vegetational reconstructions imply similar treeline and temperature depression (Van Devender et al., 1987), and estimates of $\sim 5^{\circ}-7^{\circ} \mathrm{C}$ lowering of mean annual air temperatures during the late Wisconsin derive from physical records of Great Basin lakes (Benson and Thompson, 1987). It is interesting to note that while these annual estimates of temperature differences between the last glacial maximum and present agree with the simulation results of Hostetler et al. (1994), the seasonal estimates of temperature depression implied by pollen data from Santa Barbara Basin do not. This probably reflects the problem of scale as well as the peculiar maritime climate of Santa Barbara.

It is not inconceivable that summer temperatures on the Santa Barbara coast were sometimes equal to or even higher than present during the last 160 k.y. Although this concept is consistent with descriptions of higher temperatures during the last interglacial, it is not consistent with conceptual models of regional glacial climates (Atwater et al., 1986; Hostetler et al, 1994; Van Devender et al., 1987) or with model simulations of a $6.0^{\circ} \mathrm{C}$ July temperature depression during the last glacial maximum (Hostetler et al., 1994). Depression of summer temperatures on the Santa Barbara coast is now related to the presence of fog. Temperatures of mid-montane forests above the fog are $5^{\circ} \mathrm{C}$ higher than at sea level. If changes in summer sea surface temperatures and other hydrographic features of Santa Barbara Basin resulted in the absence of fog, summer lowland temperatures, even during glacial periods, would most likely approach present-day midmontane temperatures (Pisias, 1978; Gardner and Dartnell, this volume; Hemphill-Haley and Fourtanier, this volume; Kennett, this volume).

The prominence of pollen which could be attributed to montane conifers (representatives of the Taxodiaceae, Cupressaceae, Taxaceae, and Pinus) in the record from Hole 893A is also interpreted as evidence of increased precipitation in and around Santa Barbara Basin during much of the last 160 k.y. If precipitation on the coastal lowland during glacial intervals was comparable to that of present coastal montane conifer forests, annual rainfall may have been as high as 600 to $1000 \mathrm{~mm}$ (Barbour and Major, 1977; Elford, 1974; Mehringer and Wigand, 1986; Van Devender et al., 1987; Barbour, 1988).

Even with 600 to $1000 \mathrm{~mm}$ of rainfall per year, however, Santa Barbara would have been arid during the last glacial interval. Rainfall apparently was never sufficient to support coastal forests with substantial amounts of $T$. heterophylla and/or Sequoia sempervirens. This suggests that effective precipitation was less than that of coastal central and northern California today. Estimates of precipitation reconstructed from pollen/vegetation assemblages during the last full glacial in Santa Barbara Basin agree with the 10-cm increase in precipitation during the last glacial maximum shown in the simulation results of a regional general circulation model (Hostetler et al., 1994), and with glacial precipitation estimates reconstructed from vegetation in other arid regions of the southwestern United States (Van Devender et al., 1987). 


\section{SUMMARY}

The initial results of pollen analyses of 159 samples from the 161 k.y. core from ODP Hole 893A show glacial/interglacial variations in the diagnostic taxa of vegetation assemblages of southern California. In the laminated sequence from the last interglacial (OIS-5e) pollen assemblages that are characterized by taxa representative of present coastal oak woodland, chaparral, and coastal sage scrub imply climatic conditions similar to the warm, arid conditions that have prevailed since the last glacial maximum. Pollen assemblages in the bioturbated glacial-age sediments are dominated by coniferous taxa (representatives of the Taxodiaceae, Cupressaceae, Taxaceae, and $\mathrm{Pi}$ naceae), implying comparatively cool, less arid conditions on shore. Variable representation of coniferous forest and oak woodland characterize stadial and interstadial bioturbated and intermittently laminated sediments.

During the last full-glacial cycle, changes in the composition of pollen/vegetation groups of arid coastal southern California appear to be primarily controlled by climatic change. These variations, which reflect regional atmospheric and oceanographic variations, are similar in amplitude and duration to global climatic changes reconstructed from correlative pollen and oxygen isotope data from sites outside Santa Barbara Basin.

\section{ACKNOWLEDGMENTS}

I would like to gratefully acknowledge ODP and Professor James Kennett for obtaining the Santa Barbara Basin cores. In addition, I would like to thank the reviewers (R. Byrne, O.K. Davis, and J. Gardner) for their thoughtful comments.

\section{REFERENCES}

Adam, D.P., 1988. Pollen zonation and proposed informal climatic units for Clear Lake, California, cores CL-73-4 and CL-73-7. In Sims, J.D. (Ed.), Late Quaternary Climate. Tectonism, and Sedimentation in Clear Lake. Northern California Coast Ranges. Spec. Pap.-Geol. Soc. Am., $214: 63-80$.

Adam, D.P., Sims, J.D., and Throckmorton. C.K.. 1981. 130.000-yr continuous pollen record from Clear Lake, Lake County. California. Geology; 9:373-377.

Adam, D.P., and West, G.J., 1983. Temperature and precipitation estimates through the last glacial cycle from Clear Lake, California, pollen data. Science, 219:168-170.

Anderson, R.S., and Davis, O.K., 1988. Contemporary pollen rain across the central Sierra Nevada, California, U.S.A.: relationship to modern vegetation types. Arct. Alp. Res., 20:448-460.

Atwater, B.F., Adam, D.P., Bradbury, J.P., Forrester, R.M., Mark, R.K., Lettis, W.R., Fisher, G.R., Gobalet, K.W., and Robinson. S.W.. 1986. A fan dam for Tulare Lake, California, and implications for the Wisconsin glacial history of the Sierra Nevada. Geol. Soc. Am. Bull.. 97:97-109.

Axelrod, D., 1977. Outline history of California vegetation. In Barbour. M.G., and Major, J. (Eds.), Terrestrial Vegetation of California: New York (Wiley), 139-194.

Barbour, M.G., 1988. Californian upland forests and woodland. In Barbour. M.G., and Billings, D. (Eds.), North American Terrestrial Vegetation: Cambridge (Cambridge Univ. Press), 131-164.

Barbour, M.G., and Billings, W.D., 1988. North American Terrestrial Vegetation: Cambridge (Cambridge Univ. Press).

Barbour, M.G., and Major, J., 1977. Terrestrial Vegetation of California: New York (Wiley).

Benson, L.V., and Thompson. R.S.. 1987. The physical record of lakes in the Great Basin. In Ruddiman, R.F., and Wright, H.E., Jr. (Eds.), North America and Adjacent Oceans During the Last Deglaciation: Boulder. CO (Geol. Soc. Am.), 241-260.

Byrne, R., Michaelsen, J., and Soutar, A., 1977. Fossil charcoal as a measure of wildfire frequency in southern California: a preliminary analysis
Ipaper presented at the Symp. Environ. Conseq. Fire and Fuel Manage. Mediterr. Ecosyst., Palo Alto, CA, 1970].

Callaway, R., and Davis, F., 1993. Vegetation dynamics, fire, and the physical environment in coastal central California. Ecology: 74:1567-1578.

CLIMAP Project Members, 1981. Seasonal reconstructions of the Earth's surface at the last glacial maximum. Geol. Soc. Am.. Map and Chart Ser., MC36.

Cole, K.L., and Liu, G.-W., 1994. Holocene paleoecology of an estuary on Santa Rosa Island, California. Quat. Res., 41:326-335.

Critchfield, W.B., 1971. Profiles of California vegetation. USDA For. Serv. Res. Paper PSW-76. Berkeley (Univ. Calif.), 1-54.

Cross, A.T., Thompson, G.G., and Zaitseff, J.B., 1966. Source and distribution of palynomorphs in bottom sediments, southern part of Gulf of California. Mar. Geol., 4:467-524.

Davis, M.B., Moeller, R.E., and Ford, J., 1984. Sediment focusing and pollen influx. In Haworth, E.Y.. and Lund, J.W.G. (Eds.), Lake Sediments and Environmental History: Leicester (Univ. Leicester), 261-293.

Davis, O.K.. 1992. Rapid climatic change in coastal southern California inferred from pollen analysis of San Joaquin Marsh. Quat. Res.. 37:89100.

Elford, C.R., 1974. The climate of California. In van der Leeden, F., and Troise, F.L. (Eds.), Climates of the States: Port Washington, NY (Water Info. Center), 538-594.

Fall, P.L., 1992. Pollen accumulation in a montane region of Colorado, USA: a comparison of moss polsters, atmospheric traps, and natural basins. Rev. Palaeobot. Palynol.. 72:169-197.

Gardner, J.V., Heusser, L.E., Quinterno, P.J., Stone, S.M., Barron, J.A., and Poore, R.Z.. 1988. Clear Lake record vs. the adjacent marine record: a correlation of their past 20.000 years of paleoclimatic and paleoceanographic responses. In Sims. J.D. (Ed.), Late Quaternary Climate, Tectonism. and Sedimentation in Clear Lake, Northern California Coast Ranges. Spec. Pap.-Geol. Soc. Am., 214:171-182.

Griffin, J.R., 1977. Oak woodland. In Barbour. M.G., and Major, J. (Eds.), Terrestrial Vegetation of California: New York (Wiley), 383-416.

Hanes. T.L., 1977. Chaparral. In Barbour. M.G.. and Major. J. (Eds.), Terrestrial Vegetation of California: New York (Wiley), 417-470.

Heusser, C.J., 1960. Late-Pleistocene Environments of North Pacific North America: New York (Am. Geogr. Soc.).

. 1978. Modern pollen spectra from western Oregon. Bull. Torrey Bot. Club, 105:14-17.

1983. Quaternary pollen record from Laguna de Tagua Tagua. Chile. Science, 219:1429-1432.

Heusser, C.J., and Florer, L.E., 1973. Correlation of marine and continental Quaternary pollen records from the Northeast Pacific and western Washington. Quat. Res., 3:661-670.

Heusser, C.J., and Heusser. L.E., 1990. Long continental pollen sequence from Washington State (U.S.A.): correlation of upper levels with marine pollen-oxygen isotope stratigraphy through substage 5e. Palaeogeogr., Palaeoclimatol., Palaesecol., 79:63-71.

Heusser, L., and Balsam. W.L.. 1977. Pollen distribution in the northeast Pacific Ocean. Quat. Res., 7:45-62.

Heusser. L.E.. 1978. Marine pollen in Santa Barbara Basin, California: a 12.000-yr record. Geol. Soc. Am. Bull., 89:673-678.

1988. Pollen distribution in marine sediments on the continental margin off northern California. Mar. Geol.. 80:131-147.

1994. Direct marine-terrestrial paleoclimatic correlation of the last 160,000 years: evidence from high-resolution pollen data in marine cores from the northeast Pacific Ocean. Geol. Soc. Am. Abstr. Prog., 26:1124. (Abstract)

Heusser, L.E., and Shackleton, N.J., 1979. Direct marine-continental correlation: 150,000-year oxygen isotope-pollen record from the North Pacific Science, 204:837-839.

Heusser, L.E., and Stock, C.E., 1984. Preparation techniques for concentrating pollen from marine sediments and other sediments with low pollen density. Palynology, 8:225-227.

Heusser, L.E., and van de Geer, G., 1994. Direct correlation of terrestrial and marine paleoclimatic records from four glacial-interglacial cyclesDSDP Site 594 Southwest Pacific. Quat. Sci. Rev., 13:273-282.

Hevly, R.H., Mehringer, P.J., Jr., and Yogum, H.G., 1965. Modern pollen rain in the Sonoran Desert. J. Ariz. Acad. Sci., 3:123-135.

Hostetler, S.W., Giorgi. F., Bates, G.T., and Bartlein, P.J., 1994. Lake-atmosphere feed backs associated with paleolakes Bonneville and Lahontan. Science, 263:665-667. 
Karau. M.. 1968, Statistical Report of the Pollen and Mold Committee of the American Academy of Allergy: Columbus, $\mathrm{OH}$ (Ross Lab.).

Keeley. J.E., and Keeley. S.C.. 1988. Chaparral. In Barbour, M.G., and Billings, W.D. (Eds.), North American Terrestrial Vegetation: Cambridge (Cambridge Univ. Press).

Leopold. A.S.. 1950. Vegetation zones of Mexico. Ecology, 31:507-518.

Leopold, E.B., 1967. Summary of palynological data from Searles Lake. In Pleistocene Geology and Palynology: Searles Valley, California: Searles Valley. CA (Friends of the Pleistocene), 52-66.

Macdonald, K.B., 1977. Coastal salt marsh. In Barbour, M.G., and Major. J. (Eds.), Terrestrial Vegetation of California: New York (Wiley), 263294.

Martin. P.S.. and Gray, J., 1962. Pollen analysis and the Cenozoic. Science. 137:103-111.

Mehringer, P.J., Jr., and Wigand, P.E., 1986. Western juniper in the Holocene Ipaper presented at the Pinyon-Juniper Conf., Reno. NV. 1986].

Mensing. S., 1993. The impact of European settlement on oak woodlands and fire: pollen and charcoal evidence from the Transverse Ranges. California [Ph.D. dissert.|. Univ. Calif., Berkeley.

Mooney, H.A.. 1977. Southern coastal scrub. In Barbour, M.G., and Major, J. (Eds.). Terrestrial Vegetation of California: New York (Wiley), 47I490.

Morgan. T.. Cummings. L.S., Rudolph. J., and Woodman, C.. 1994. Late Pleistocene and Holocene Paleoclimatic reconstructions in the Lower Santa Ynez River Valley, Santa Barbara County, California. In AMQUA Abstr.: Minneapolis (Univ. Minnesota), 233. (Abstract)

Mudie, P.J., 1975. Palynology of recent coastal lagoon sediments in southern and central California. In Miller, C.N. (Ed.), Abstr. Bot. Soc. Am. Meet.. Corvallis. OR. 22. (Abstract)

Mudie, P.J., and Byrne, R., 1980. Pollen evidence for historic sedimentation rates in California coastal marshes. Estuarine Coastal Mar. Sci., 10:305316.

Munz, P.A., 1968. A California Flora: Berkeley (Univ, Calif. Press).

Namias, J.. 1971. The 1968-1969 winter as an outgrowth of sea and air coupling during antecedent seasons. J. Phvs. Oceanogr., 1:65-81.

Peterson, S., 1980. Late Holocene sedimentation at Zaca Lake, Santa Barbara County, California [B.S. thesis]. Univ, California, Berkeley,

Pisias, N.G.. 1978. Paleoceanography of the Santa Barbara Basin during the last 8000 years. Quat. Res., 10:366-384.

Rypins, S.. Reneau. S.L.. Byrne. R.. and Montgomery, D.R.. 1989. Palynologic and geomorphic evidence for environmental change during the Pleistocene-Holocene transition at Point Reyes Peninsula, central coastal California. Quat. Res., 32:72-87.

Schimmelmann. A., and Tegner, M.J., 1992. Historical evidence of abrupt coastal climatic change in southern California, 1790-1880. In Redmond, K. (Ed.), Proc. Puclim Conf.. Asilomar, CA (Calif. Dept. Water Res.), $47-56$.

Sharp, R.P., Allen, C.R.. and Meier, M.F.. 1959. Pleistocene glaciers on southern California mountains. Am. J. Sci.. 257:81-94.

Shore-based Scientific Party, 1994. Site 893. In Kennett, J.P., Baldauf, J.G.. et al., Proc. ODP, Init. Repts., 146 (Pt. 2): College Station. TX (Ocean Drilling Program). 15-50.
Sims, J.D., Adam, D.P., and Rymer, M.J., 1981. Late Pleistocene stratigraphy and palynology of Clear Lake, Lake County, California. In McLaughlin, R.J., and Donnelly-Nolan, J.M. (Eds.), Research in the Geysers-Clear Lake Geothermal Area, Northern California. Geol. Surv. Prof. Pap. U.S., 1141:219-230.

Singh, G.. Kershaaw, A.P., and Clark, R., 1981. Quaternary vegetation and fire history in Australia. In Groves, R.A., and Noble, I.R. (Eds.), Fire and Australian Biota: Canberra (Aust. Acad. Sci.), 23-54.

Solomon, A.M., 1972. Predictive models of airborne pollen concentrations: uncertainties in pollen production estimates. In Benninghoff, W.S., and Edmonds, R.L. (Eds.), Ecological Svstems Approaches to Aerobiology II: Development, Demonstration and Evaluation of Models: Boulder, CO (US/IBP Aerobiology Program), 1-17.

Solomon, A.M., and Hayes, H.D.. 1972. Desert pollen production, 1. Qualitative influence of moisture. J. Ariz. Acad. Sci., 7:52-74.

Solomon, A.M., and Silkworth, A.B., 1986. Spatial patterns of atmospheric pollen transport in a montane region. Quat. Res., 25:150-162.

Soutar. A., and Crill, P.A.. 1977. Sedimentation and climatic patterns in the Santa Barbara Basin during the 19th and 20th centuries. Geol. Soc. Am. Bull., 88:1161-1172.

Thorne, R.F., 1977. Montane and subalpine forests of the Transverse and Peninsular Ranges. In Barbour. M.G.. and Major. J. (Eds.). Terrestrial Vegetation of California: New York (Wiley), 537-558.

Traverse, A., 1988. Paleopalynology: Boston (Unwyn Hyman).

Van Devender, T.R.. Thompson, R.S., and Betancourt, J.L., 1987. Vegetation history of the deserts of southwestern North America: the nature and timing of the Late Wisconsin-Holocene transition. In Ruddiman, W.F., and Wright, H.E., Jr. (Eds.). North American and Adjacent Oceans During the Last Deglaciation: Boulder. CO (Geol. Soc. Am.), 323-352.

Vasek, F.C., and Thorne, R.F., 1977. Transmontane coniferous vegetation. In Barbour, M.G., and Major, J. (Eds.), Terrestrial Vegetation of California: New York (Wiley), 797-834.

Vogl, R.J., Armstrong, W.P., White, K.L., and Cole, K.L., 1977. The closedcone pine and cypresses. In Barbour, M.G., and Major, J. (Eds.), Terrestrial Vegetation of California: New York (Wiley), 295-358.

Weldon, R.J.. 1983. Climatic control for the formation of terraces in Cajon Creek. Southern California. Geol. Soc. Am. Abstr. Progr, 15:429. (Abstract)

West, G.J., 1994. A Late Pleistocene pollen record from San Miguel Island, California: preliminary results. In AMQUA Abstr.: Minneapolis (Univ. Minnesota), 256. (Abstract)

Woillard, G.. 1978. Grande Pile Bog: a continuous pollen record for the last 140,000 years. Quat. Res., 9:1-21.

\footnotetext{
Date of initial receipt: 18 August 1994

Date of acceptance: 13 February 1995

Ms 146SR-279
} 
APPENDIX A

Varimax Factor Matrix of Pollen Data from Hole 893A

\begin{tabular}{lcccccc}
\hline \multicolumn{1}{c}{ Pollen type } & Factor 1 & Factor 2 & Factor 3 & Factor 4 & Factor 5 & Factor 6 \\
\hline Pinus & -0.0449 & 0.0608 & 0.9935 & 0.0281 & 0.0384 & 0.0653 \\
Tsuga & 0 & 0.0001 & 0.0003 & -0.0005 & 0.0018 & 0.0021 \\
Abies & -0.0011 & -0.0003 & 0.0063 & -0.0011 & 0.0013 & 0.0045 \\
Picea & -0.0005 & 0.0008 & 0.0052 & 0.0016 & -0.0201 & -0.0083 \\
Quercus & -0.0491 & 0.6221 & -0.0515 & 0.6296 & -0.4307 & 0.158 \\
Alnus & -0.0073 & 0.0444 & -0.0116 & 0.1189 & 0.249 & -0.0081 \\
Betulaceae & -0.0003 & 0.0005 & 0.0021 & 0.0023 & -0.0007 & -0.0062 \\
Juglans & -0.0009 & 0.0032 & 0.0023 & 0.015 & -0.0079 & -0.0029 \\
Ilex & -0.0004 & 0.0003 & 0.0017 & -0.0012 & 0.0008 & 0.0025 \\
RRA & 0.0259 & 0.2036 & -0.0628 & 0.3354 & 0.7704 & 0.0172 \\
Ephedra & -0.0023 & 0.0061 & 0.0047 & 0.0154 & 0.0102 & -0.0114 \\
Gramineae & -0.0013 & 0.027 & 0.002 & 0.004 & 0.0082 & -0.023 \\
Cyperaceae & -0.0008 & 0.0063 & 0.0053 & 0.0145 & -0.0058 & -0.014 \\
Compositae & 0.0608 & 0.7067 & -0.0263 & -0.6782 & 0.0177 & 0.0029 \\
Artemisia & 0.0609 & 0.1776 & 0.0532 & 0.1059 & 0.0741 & -0.9267 \\
Chenopodiaceae & 0.0085 & 0.1829 & -0.0271 & -0.0282 & 0.3857 & 0.3264 \\
TCT & 0.9937 & -0.0271 & 0.0425 & 0.0598 & -0.0467 & 0.064 \\
\% sum of squares & 59.264 & 26.587 & 12.064 & 1.053 & 0.415 & 0.369 \\
\hline
\end{tabular}

APPENDIX B

Varimax Factor Scores of Pollen Data from Hole 893A

\begin{tabular}{|c|c|c|c|c|c|c|c|}
\hline $\begin{array}{l}\text { Depth } \\
\text { (mbsf) }\end{array}$ & Communality & Factor I & Factor 2 & Factor 3 & Factor 4 & Factor 5 & Factor 6 \\
\hline 0.018 & 0.998 & 0.131 & 0.767 & 0.599 & 0.070 & -0.162 & 0.045 \\
\hline 0.042 & 0.998 & 0.031 & 0.864 & 0.416 & 0.246 & -0.127 & -0.022 \\
\hline 0.076 & 0.994 & 0.001 & 0.841 & 0.479 & 0.201 & 0.025 & -0.128 \\
\hline 0.891 & 0.995 & 0.019 & 0.985 & 0.045 & 0.080 & -0.116 & -0.057 \\
\hline 1.778 & 0.997 & 0.067 & 0.944 & 0.227 & -0.215 & -0.045 & 0.045 \\
\hline 2.692 & 0.996 & 0.065 & 0.907 & 0.390 & -0.081 & -0.096 & 0.041 \\
\hline 3.606 & 0.997 & 0.030 & 0.938 & 0.283 & 0.155 & -0.064 & 0.094 \\
\hline 3.917 & 0.998 & 0.039 & 0.984 & 0.132 & 0.081 & -0.017 & -0.066 \\
\hline 4.873 & 0.999 & 0.055 & 0.994 & -0.007 & 0.003 & -0.087 & -0.011 \\
\hline 5.788 & 0.995 & 0.098 & 0.974 & 0.156 & 0.063 & -0.084 & 0.051 \\
\hline 6.692 & 0.992 & 0.270 & 0.945 & 0.053 & -0.148 & 0.029 & 0.012 \\
\hline 7.539 & 0.999 & 0.046 & 0.904 & 0.415 & -0.057 & -0.034 & 0.060 \\
\hline 8.397 & 0.995 & 0.052 & 0.969 & 0.063 & -0.218 & -0.030 & 0.004 \\
\hline 9.332 & 0.992 & 0.116 & 0.969 & 0.145 & -0.097 & -0.093 & 0.037 \\
\hline 9.680 & 0.997 & 0.274 & 0.943 & 0.027 & -0.117 & 0.131 & 0.017 \\
\hline 10.022 & 0.996 & 0.234 & 0.961 & 0.049 & -0.031 & 0.105 & 0.051 \\
\hline 10.048 & 0.996 & 0.091 & 0.788 & 0.545 & 0.121 & -0.234 & 0.031 \\
\hline 10.305 & 0.995 & 0.177 & 0.940 & 0.088 & 0.076 & 0.252 & -0.054 \\
\hline 10.635 & 0.972 & 0.124 & 0.937 & 0.221 & -0.164 & 0.032 & -0.045 \\
\hline 11.025 & 0.994 & 0.121 & 0.975 & 0.060 & -0.076 & -0.017 & -0.141 \\
\hline 11.357 & 0.989 & 0.197 & 0.948 & 0.007 & -0.062 & 0.199 & -0.091 \\
\hline 11.688 & 0.979 & 0.185 & 0.938 & 0.064 & 0.210 & 0.123 & -0.038 \\
\hline 12.014 & 0.998 & 0.011 & 0.450 & 0.890 & 0.011 & -0.029 & 0.038 \\
\hline 12.347 & 0.985 & 0.233 & 0.941 & -0.018 & 0.091 & 0.191 & 0.024 \\
\hline 12.647 & 0.993 & 0.591 & 0.754 & 0.104 & 0.232 & 0.059 & -0.082 \\
\hline 12.987 & 0.998 & 0.077 & 0.524 & 0.843 & 0.031 & -0.073 & 0.047 \\
\hline 13.322 & 0.998 & 0.620 & 0.577 & 0.480 & 0.203 & 0.003 & 0.096 \\
\hline 13.656 & 0.998 & 0.673 & 0.655 & 0.179 & 0.287 & 0.046 & -0.031 \\
\hline 13.938 & 0.997 & 0.300 & 0.829 & 0.028 & 0.464 & 0.004 & 0.059 \\
\hline 14.226 & 0.996 & 0.604 & 0.704 & 0.244 & 0.264 & -0.076 & -0.013 \\
\hline 14.522 & 0.997 & 0.827 & 0.476 & 0.203 & 0.194 & 0.073 & 0.048 \\
\hline 14.852 & 0.999 & 0.098 & 0.209 & 0.970 & 0.032 & 0.036 & 0.054 \\
\hline 15.809 & 0.999 & 0.043 & 0.169 & 0.984 & -0.004 & 0.029 & 0.013 \\
\hline 16.397 & 1.000 & 0.069 & 0.186 & 0.977 & -0.037 & 0.057 & -0.039 \\
\hline 17.251 & 1.000 & 0.370 & 0.209 & 0.904 & -0.021 & 0.028 & -0.022 \\
\hline 18.203 & 0.998 & 0.564 & 0.495 & 0.588 & -0.156 & 0.024 & -0.254 \\
\hline 19.171 & 0.999 & 0.449 & 0.383 & 0.797 & -0.068 & 0.027 & -0.100 \\
\hline 20.019 & 0.995 & 0.837 & 0.237 & 0.477 & -0.072 & 0.022 & -0.073 \\
\hline 20.951 & 1.000 & 0.939 & 0.269 & 0.175 & -0.092 & 0.010 & -0.078 \\
\hline 21.961 & 1.000 & 0.917 & 0.223 & 0.320 & -0.036 & 0.017 & -0.068 \\
\hline 22.890 & 0.999 & 0.947 & 0.187 & 0.248 & -0.058 & -0.013 & -0.048 \\
\hline 23.809 & 1.000 & 0.960 & 0.107 & 0.257 & 0.007 & -0.011 & -0.002 \\
\hline 24.743 & 1.000 & 0.987 & 0.098 & 0.127 & -0.005 & -0.016 & -0.012 \\
\hline 25.685 & 1.000 & 0.992 & 0.080 & 0.096 & 0.021 & -0.022 & 0.006 \\
\hline 26.630 & 1.000 & 0.831 & 0.210 & 0.513 & -0.038 & 0.002 & -0.027 \\
\hline 27.647 & 1.000 & 0.949 & 0.071 & 0.304 & 0.021 & -0.021 & 0.033 \\
\hline 28.932 & 1.000 & 0.968 & 0.081 & 0.232 & 0.028 & -0.007 & 0.039 \\
\hline 29.947 & 1.000 & 0.713 & 0.252 & 0.650 & -0.051 & 0.025 & -0.045 \\
\hline 31.695 & 1.000 & 0.967 & 0.083 & 0.235 & 0.037 & 0.000 & 0.036 \\
\hline 32.659 & 1.000 & 0.738 & 0.140 & 0.657 & 0.030 & -0.002 & 0.058 \\
\hline 33.688 & 1.000 & 0.844 & 0.135 & 0.519 & -0.004 & 0.013 & 0.017 \\
\hline 34.739 & 0.999 & 0.962 & 0.125 & 0.229 & 0.039 & 0.011 & 0.055 \\
\hline 35.717 & 1.000 & 0.784 & 0.230 & 0.574 & $-0,015$ & 0.025 & -0.044 \\
\hline 36.840 & 1.000 & 0.936 & 0.226 & 0.268 & -0.011 & -0.022 & -0.002 \\
\hline 37.588 & 1.000 & 0.584 & 0.198 & 0.786 & -0.007 & 0.028 & 0.022 \\
\hline 38.415 & 0.999 & 0.632 & 0.171 & 0.753 & 0.018 & 0.041 & 0.032 \\
\hline 39.365 & 0.999 & 0.834 & 0.124 & 0.535 & 0.033 & 0.011 & 0.025 \\
\hline
\end{tabular}


APPENDIX B (continued).

\begin{tabular}{|c|c|c|c|c|c|c|c|}
\hline $\begin{array}{l}\text { Depth } \\
\text { (mbsf) }\end{array}$ & Communality & Factor 1 & Factor 2 & Factor 3 & Factor 4 & Factor 5 & Factor 6 \\
\hline 40.409 & 1.000 & 0.951 & 0.088 & 0.292 & 0.040 & -0.005 & 0.042 \\
\hline 41.473 & 1.000 & 0.935 & 0.139 & 0.324 & 0.025 & 0.011 & 0.037 \\
\hline 42.531 & 0.999 & 0.749 & 0.160 & 0.641 & 0.045 & 0.014 & 0.016 \\
\hline 43.6 .32 & 1.000 & 0.978 & 0.146 & 0.126 & 0.055 & -0.022 & 0.040 \\
\hline 43.740 & 1.000 & 0.992 & 0.114 & 0.045 & 0.033 & -0.007 & 0.021 \\
\hline 44.726 & 1.000 & 0.992 & 0.107 & 0.065 & 0.000 & -0.010 & 0.004 \\
\hline 45.517 & 1.000 & 0.994 & 0.072 & 0.058 & 0.034 & -0.026 & 0.028 \\
\hline 46.309 & 0.999 & 0.965 & 0.233 & 0.114 & -0.006 & 0.021 & 0.019 \\
\hline 47.359 & 1.000 & 0.981 & 0.187 & 0.050 & 0.017 & 0.009 & 0.003 \\
\hline 48.359 & 1.000 & 0.906 & 0.163 & 0.390 & -0.001 & 0.013 & 0.021 \\
\hline 49.244 & 1.000 & 0.993 & 0.105 & 0.059 & -0.003 & -0.004 & -0.009 \\
\hline 50.468 & 0.999 & 0.952 & 0.275 & 0.124 & 0.026 & 0.004 & 0.000 \\
\hline 51.430 & 0.998 & 0.863 & 0.453 & 0.085 & 0.001 & 0.096 & -0.178 \\
\hline 52.493 & 1.000 & 0.936 & 0.346 & 0.034 & 0.001 & 0.035 & -0.033 \\
\hline 53.547 & 0.999 & 0.863 & 0.345 & 0.346 & -0.083 & 0.090 & -0.025 \\
\hline 54.702 & 1.000 & 0.918 & 0.305 & 0.230 & -0.061 & 0.048 & -0.070 \\
\hline 55.925 & 1.000 & 0.934 & 0.267 & 0.238 & -0.012 & 0.015 & -0.007 \\
\hline 56.052 & 1.000 & 0.907 & 0.400 & 0.086 & -0.045 & 0.065 & -0.068 \\
\hline 57.224 & 1.000 & 0.947 & 0.296 & 0.114 & -0.031 & 0.022 & -0.020 \\
\hline 58.371 & 1.000 & 0.795 & 0.152 & 0.587 & 0.012 & -0.007 & 0.016 \\
\hline 59.552 & 1,000 & 0.278 & 0.131 & 0.949 & 0.048 & 0.007 & 0.045 \\
\hline 60.800 & 1.000 & 0.685 & 0.191 & 0.703 & 0.017 & 0.000 & 0.013 \\
\hline 62.124 & 1.000 & 0.980 & 0.122 & 0.153 & 0.000 & -0.024 & -0.008 \\
\hline 63.372 & 0.999 & 0.913 & 0.263 & 0.298 & -0.058 & 0.043 & -0.038 \\
\hline 64.620 & 1.000 & 0.769 & 0.175 & 0.613 & 0.010 & 0.041 & 0.020 \\
\hline 65.363 & 0.999 & 0.923 & 0.261 & 0.266 & -0.067 & 0.009 & -0.066 \\
\hline 66.763 & 1.000 & 0.986 & 0.101 & 0.133 & 0.009 & -0.016 & 0.012 \\
\hline 68.270 & 1.000 & 0.938 & 0.299 & 0.118 & -0.080 & 0.024 & -0.099 \\
\hline 69.872 & 1.000 & 0.959 & 0.263 & 0.076 & -0.040 & 0.011 & -0.065 \\
\hline 71.443 & 0.999 & 0.816 & 0.533 & 0.123 & -0.026 & 0.057 & -0.176 \\
\hline 72.821 & 0.999 & 0.947 & 0.275 & 0.057 & -0.089 & 0.080 & -0.091 \\
\hline 73.612 & 0.999 & 0.942 & 0.254 & 0.175 & -0.070 & 0.013 & -0.107 \\
\hline 76.925 & 0.999 & 0.854 & 0.498 & 0.141 & 0.019 & 0.034 & 0.001 \\
\hline 78.346 & 0.997 & 0.895 & 0.416 & 0.071 & -0.009 & 0.133 & 0.004 \\
\hline 79.906 & 0.999 & 0.901 & 0.417 & 0.073 & 0.002 & 0.088 & 0.013 \\
\hline 81.476 & 0.999 & 0.723 & 0.610 & 0.304 & 0.011 & 0.101 & 0.046 \\
\hline 82.983 & 0.999 & 0.502 & 0.837 & 0.135 & -0.117 & 0.064 & -0.104 \\
\hline 83.475 & 1.000 & 0.984 & 0.114 & 0.126 & 0.036 & -0.016 & 0.048 \\
\hline 84.896 & 1.000 & 0.858 & 0.212 & 0.466 & 0.028 & -0.003 & -0.006 \\
\hline 85.302 & 0.999 & 0.917 & 0.379 & 0.115 & 0.020 & 0.009 & -0.039 \\
\hline 87.086 & 0.988 & 0.804 & 0.486 & 0.215 & -0.154 & 0.120 & -0.147 \\
\hline 88.326 & 0.999 & 0.890 & 0.340 & 0.293 & -0.004 & 0.027 & -0.056 \\
\hline 88.539 & 0.999 & 0.950 & 0.284 & 0.105 & -0.010 & 0.014 & -0.061 \\
\hline 89.886 & 1.000 & 0.988 & 0.103 & 0.103 & 0.037 & -0.023 & 0.029 \\
\hline 90.003 & 1.000 & 0.947 & 0.054 & 0.305 & 0.054 & -0.018 & 0.063 \\
\hline 90.412 & 0.999 & 0.935 & 0.268 & 0.230 & -0.010 & 0.030 & -0.016 \\
\hline 91.994 & 0.999 & 0.915 & 0.375 & 0.109 & 0.081 & -0.022 & -0.042 \\
\hline 93.586 & 1.000 & 0.956 & 0.264 & 0.083 & 0.077 & -0.046 & 0.010 \\
\hline 94,601 & 1.000 & 0.963 & 0.236 & 0.122 & 0.016 & 0.014 & -0.030 \\
\hline 96.225 & 0.997 & 0.891 & 0.415 & 0.089 & -0.080 & 0.127 & -0.012 \\
\hline 97.860 & 1.000 & 0.981 & 0.098 & 0.149 & 0.038 & -0.019 & 0.055 \\
\hline 99.463 & 0.998 & 0.893 & 0.409 & 0.150 & 0.095 & 0.003 & 0.031 \\
\hline 101.040 & 1.000 & 0.948 & 0.302 & 0.069 & 0.064 & 0.018 & 0.029 \\
\hline 101.470 & 0.998 & 0.487 & 0.676 & 0.506 & -0.192 & 0.111 & -0.011 \\
\hline 103.050 & 0.988 & 0.605 & 0.758 & 0.093 & -0.155 & 0.121 & -0.005 \\
\hline 104.610 & 0.999 & 0.880 & 0.466 & 0.064 & -0.044 & -0.027 & 0.039 \\
\hline 104.750 & 0.999 & 0.851 & 0.486 & 0.151 & 0.106 & 0.064 & 0.012 \\
\hline 106.040 & 0.999 & 0.396 & 0.870 & 0.187 & 0.213 & 0.022 & 0.062 \\
\hline 107.670 & 0.999 & 0.235 & 0.955 & 0.006 & 0.111 & -0.117 & -0.073 \\
\hline 109.300 & 0.994 & 0.356 & 0.910 & 0.131 & 0.116 & -0.082 & 0.045 \\
\hline 111.020 & 0.998 & 0.893 & 0.357 & 0.263 & 0.027 & 0.001 & 0.059 \\
\hline 112.740 & 0.999 & 0.878 & 0.413 & 0.218 & 0.061 & 0.065 & 0.036 \\
\hline 114.340 & 0.999 & 0.922 & 0.263 & 0.246 & 0.106 & -0.036 & 0.083 \\
\hline 114.850 & 0.998 & 0.785 & 0.577 & 0.204 & -0.041 & 0.037 & 0.063 \\
\hline 116.150 & 0.979 & 0.751 & 0.609 & 0.156 & -0.105 & 0.090 & 0.006 \\
\hline 117.580 & 0.996 & 0.390 & 0.897 & -0.014 & -0.158 & 0.049 & 0.103 \\
\hline 119.170 & 0.999 & 0.404 & 0.894 & 0.071 & -0.174 & -0.009 & 0.032 \\
\hline 120.650 & 0.997 & 0.790 & 0.578 & 0.072 & 0.115 & -0.056 & 0.131 \\
\hline 122.120 & 0.997 & 0.321 & 0.929 & 0.112 & 0.040 & -0.093 & 0.085 \\
\hline 123.050 & 0.999 & 0.396 & 0.857 & 0.133 & -0.295 & 0.040 & 0.039 \\
\hline 123.360 & 0.941 & 0.269 & 0.882 & 0.271 & 0.011 & 0.133 & 0.020 \\
\hline 124.050 & 0.989 & 0.239 & 0.920 & 0.204 & 0.153 & -0.015 & 0.143 \\
\hline 124.770 & 0.999 & 0.731 & 0.663 & 0.025 & 0.155 & 0.014 & 0.029 \\
\hline 125.500 & 0.998 & 0.509 & 0.839 & 0.080 & -0.143 & 0.050 & -0.078 \\
\hline 126.250 & 0.997 & 0.900 & 0.299 & 0.252 & 0.158 & 0.042 & 0.089 \\
\hline 126.950 & 0.999 & 0.703 & 0.236 & 0.660 & 0.096 & 0.002 & 0.074 \\
\hline 128.210 & 1.000 & 0.980 & 0.063 & 0.139 & 0.095 & -0.038 & 0.076 \\
\hline 128.610 & 0.999 & 0.973 & 0.103 & 0.188 & 0.043 & -0.006 & 0.069 \\
\hline 129.920 & 1.000 & 0.953 & 0.178 & 0.235 & 0.023 & -0.019 & 0.059 \\
\hline 131.220 & 1.000 & 0.962 & 0.138 & 0.231 & 0.014 & -0.003 & 0.047 \\
\hline 132.650 & 1.000 & 0.985 & 0.036 & 0.133 & 0.068 & -0.042 & 0.068 \\
\hline 133.950 & 1.000 & 0.978 & 0.115 & 0.168 & -0.011 & -0.018 & 0.027 \\
\hline 135.260 & 1.000 & 0.967 & 0.150 & 0.203 & -0.035 & 0.023 & 0.012 \\
\hline 136.510 & 1.000 & 0.996 & 0.048 & 0.046 & 0.030 & -0.018 & 0.039 \\
\hline 137.150 & 1.000 & 0.987 & 0.132 & 0.089 & -0.004 & 0.040 & 0.011 \\
\hline 138.460 & 1.000 & 0.992 & 0.109 & 0.053 & -0.006 & -0.022 & 0.031 \\
\hline 139.760 & 1.000 & 0.990 & 0.122 & 0.063 & 0.001 & -0.018 & 0.008 \\
\hline 142.460 & 1.000 & 0.928 & 0.069 & 0.357 & 0.060 & -0.014 & 0.049 \\
\hline 143.800 & 1.000 & 0.923 & 0.368 & 0.033 & -0.042 & 0.093 & -0.018 \\
\hline
\end{tabular}


APPENDIX B (continued).

\begin{tabular}{rccccccr}
\hline $\begin{array}{c}\text { Depth } \\
\text { (mbsf) }\end{array}$ & Communality & Factor 1 & Factor 2 & Factor 3 & Factor 4 & Factor 5 & Factor 6 \\
\hline 145.710 & 1.000 & 0.993 & 0.096 & 0.071 & 0.009 & -0.001 & 0.017 \\
146.930 & 0.999 & 0.956 & 0.228 & 0.157 & 0.026 & 0.077 & 0.039 \\
148.280 & 0.997 & 0.919 & 0.351 & 0.147 & -0.081 & 0.038 & -0.001 \\
149.560 & 0.998 & 0.865 & 0.250 & 0.425 & -0.010 & 0.073 & -0.024 \\
150.900 & 0.996 & 0.807 & 0.476 & 0.257 & -0.177 & 0.124 & -0.063 \\
152.250 & 1.000 & 0.887 & 0.183 & 0.418 & -0.005 & 0.041 & 0.055 \\
153.590 & 0.998 & 0.822 & 0.517 & 0.114 & -0.170 & 0.076 & -0.085 \\
154.350 & 0.999 & 0.547 & 0.331 & 0.756 & -0.122 & 0.063 & -0.007 \\
155.110 & 1.000 & 0.975 & 0.196 & 0.099 & -0.001 & 0.036 & 0.014 \\
156.580 & 1.000 & 0.911 & 0.339 & 0.074 & -0.161 & 0.049 & -0.143 \\
157.950 & 0.999 & 0.977 & 0.191 & 0.078 & -0.007 & 0.001 & 0.030 \\
159.350 & 1.000 & 0.987 & 0.147 & 0.065 & 0.009 & -0.001 & -0.006 \\
160.700 & 1.000 & 0.991 & 0.059 & 0.068 & 0.071 & -0.032 & 0.065 \\
\hline
\end{tabular}

